\title{
REVIEW
}

Open Access

\section{A global systematic scoping review of studies analysing indicators, development, and content of national-level physical activity and sedentary behaviour policies}

Bojana Klepac Pogrmilovic', Grant O'Sullivan', Karen Milton², Stuart J. H. Biddle ${ }^{3}$, Adrian Bauman', Fiona Bull ${ }^{5,6}$, Sonja Kahlmeier ${ }^{7}$, Michael Pratt $^{8}$ and Zeljko Pedisic ${ }^{1^{*}}$

\begin{abstract}
Background: National policy approaches to physical activity (PA) promotion and sedentary behaviour (SB) reduction are needed to address rising rates of non-communicable diseases. Understanding the policy process and impact through robust research and evaluation is crucial for facilitating successful reforms in national health policy. This scoping review, therefore, aimed to map the evidence on indicators, development, and content of national PA and/or SB policies globally.

Methods: A systematic search of academic and grey literature was conducted through six bibliographic databases, Google, and websites of three large organisations for PA promotion.

Results: Out of 24,872 screened documents, 203 publications from 163 studies were selected. The selected studies investigated PA/SB policies in 168 countries worldwide, and we provided summary results for each of the countries. Overall, 69, 29, and 2\% of the analyses of national PA/SB policies were conducted for high-, middle-, and low-income countries, respectively. Twenty-two percent of the studies mentioned SB policies as part of their analysis, with only one study focusing solely on assessing SB policies. Operational definitions of policy were found in only $13 \%$ of publications. Only $15 \%$ of the studies used a conceptual or theoretical framework. A large variety of methods were used for data collection and analysis of PA/SB policy.

Conclusions: We found that PA policy research is much more developed than it was considered several years ago. Research around SB policies is still in its infancy, but it seems to have experienced some positive progress in the last few years. Three key issues were identified that should be addressed in further research: [i] there is a lack of PA/SB policy research in low- and middle-income countries, which is an important limitation of the current body of evidence; [ii] the definition of policy varied significantly across studies, and most studies did not rely on any theoretical framework, which may impede cross-study comparisons; and [iii] studies have used a variety of methods to analyse policy, which may also cause problems with comparability. Future PA/SB policy research should aim towards a clearer conceptualisation of policy, greater reliance on existing theoretical frameworks, and the use and further development of standardised methods for PA/SB policy analysis.
\end{abstract}

Keywords: Physical activity, National policy, Sedentary behaviour, Sitting, Physical inactivity, National plan, Strategy

\footnotetext{
* Correspondence: zeljko.pedisic@vu.edu.au

${ }^{1}$ Institute for Health and Sport, Victoria University, Ballarat Road, Footscray,

Melbourne, VIC 3001, Australia

Full list of author information is available at the end of the article
}

(c) The Author(s). 2018 Open Access This article is distributed under the terms of the Creative Commons Attribution 4.0 International License (http://creativecommons.org/licenses/by/4.0/), which permits unrestricted use, distribution, and reproduction in any medium, provided you give appropriate credit to the original author(s) and the source, provide a link to the Creative Commons license, and indicate if changes were made. The Creative Commons Public Domain Dedication waiver (http://creativecommons.org/publicdomain/zero/1.0/) applies to the data made available in this article, unless otherwise stated. 


\section{Background}

More than 40 million people a year die from noncommunicable diseases (NCDs), of which 15 million deaths are considered premature [1]. This accounts for around $70 \%$ of overall global mortality [2], with high rates in low-, middle-, and high-income countries [1]. Insufficient physical activity (PA) and sedentary behaviour (SB) are among the key risk factors for NCDs. Global estimates indicate that the latter was responsible for $3.8 \%$ of deaths from 2002 to 2011 [3] and the former for $9 \%$ of deaths in 2008 [4]. In 2013, the estimated cost of insufficient PA to worldwide health-care systems was around 53.8 billion international dollars [5]. Insufficient PA and prolonged sitting are, therefore, not just significant health risk factors for global mortality but also a vast economic burden for national health care systems. National policy approaches to PA promotion and SB reduction are an essential aspect needed to address rising rates of NCDs [6].

The policy environment is perceived as one of the important determinants influencing active living at the population level [7]. The main goals of public policy related to PA are to allow for creating supportive programs, infrastructure, and environments for people to engage in physically active lifestyles $[8,9]$. Research related to PA has informed the development of policy in the health sector and non-health sectors such as education, transport, sport, and environment [10-12]. PA policy research has been developing since 1990s. This field of research lagged behind the research on health outcomes of PA by more than 30 years $[13,14]$. Therefore, PA policy research is still widely considered to be an area in need of more research, particularly in terms of large-scale evaluations of implementation and impact $[13,15,16]$.

Since 2000, two key global efforts have occurred in PA planning and policy [17]. In 2002, The World Health Organization (WHO) and the Centers for Disease Control and Prevention (CDC) in the United States of America (USA) conducted international consultations on PA policy development [18]. The consultations informed the development of the Global Strategy on Diet, Physical Activity and Health, which is perceived to be the first major global effort related to PA policy [19]. The strategy targeted governments, along with non-governmental agencies, as the main agents of social change that can enhance population PA levels by creating supportive environments. The second major initiative was the United Nations (UN) high-level meeting on NCDs in 2011, where physical inactivity was acknowledged as an important determinant of NCDs globally [17]. Along with these major global efforts, various international leadership and advocacy networks were established to support the promotion of PA, such as: Red Actividad Fisica de las Americas/Physical Activity Network of the Americas (RAFA/PANA) in 2000; Asia Pacific Physical Activity Network (AP-PAN) and the European Network for the Promotion of Health-Enhancing Physical Activity (HEPA Europe) in 2005; Global Advocacy for Physical Activity (GAPA) in 2007; Africa Physical Activity Network (AFRO-PAN) in 2010; Global Observatory for Physical Activity (GoPA!) in 2012; and Active Healthy Kids Global Alliance in 2014.

Studies on SB form a relatively new field of behavioural epidemiology. Interest in this area has started growing rapidly in the last decade, after epidemiological evidence indicated that long periods of sitting might pose a health risk, irrespective of one's PA level [20]. It should be noted, however, that recent studies have questioned the validity of evidence on $\mathrm{SB}$ as an independent health risk factor [21-24]. The main goals of emerging SB related public policy is to allow for creating supportive programs, infrastructure, and environments to support people to minimise their time spent in $\mathrm{SB}$ and to break prolonged periods of SB. Although evidence on the prevalence, trends, determinants, and health outcomes of SB is emerging rapidly, the research around SB policies is scarce and still in its infancy. The Sedentary Behaviour Research Network was recently established as an international association for researchers and health professionals focusing specifically on $\mathrm{SB}$, to support research in this area [25].

The development of the Global Strategy on Diet, Physical Activity and Health, along with several other global awareness-raising initiatives from the early 2000s, was viewed as a potential turning point after which more countries would establish national policies and strategies related to PA [26]. However, after a decade, the majority of countries had made limited progress on PA policy development $[27,28]$. It has been suggested that further research is needed to provide new theoretical and practical insights to inform future PA and SB policy development $[16,17]$. Understanding the policy process and impact through robust research and evaluation is crucial for facilitating successful reforms in national health policy [29] and to support all countries to prioritise and commit to increasing PA promotion [30].

A comparative scoping review from 2016 analysed three types of scientific evidence to inform physical activity policy [31] and a structured literature review and citation network analysis published in 2018 mapped the historical development of PA and health research [13]. However, the actual level of development of the PA/SB policy research has never been systematically evaluated. This systematic scoping review of academic and grey literature aimed to map the evidence on the indicators, development, and content of national $\mathrm{PA}$ and/or SB policies. We addressed the following four key questions: 
(i) Which countries and world regions have been covered by this type of research?; (ii) How is 'policy' conceptualised within the studies and to what extent were PA/ SB policy studies based on conceptual/theoretical frameworks?; (iii) Which methods have been used for analysing PA/SB policies?; and (iv) What are the potential future directions of research in this area? This review will help inform national PA/SB policy development, public health promotion of physically active lifestyles, and future research on PA and/or SB policies.

\section{Methods}

\section{Literature search}

The primary search was performed through PubMed/ MEDLINE, Scopus, Web of Science (including Science Citation Index Expanded - SCI-EXPANDED, Social Sciences Citation Index - SSCI, Arts \& Humanities Citation Index - A\&HCI, Conference Proceedings Citation Index-Science - CPCI-S, and Conference Proceedings Citation Index- Social Science \& Humanities - CPCISSH), SPORTDiscus, Open Access Theses and Dissertations (OATD), and Networked Digital Library of Theses and Dissertations (NDLTD) databases using the entries "physical inactivity", "physical activity", sitting, and sedentar" in combination with the entries policy and policies. The full search syntaxes used for each database are available in Additional file 1. The search was performed through titles, abstracts and keywords of the articles. The secondary search was done through the references of all articles selected in the primary search and authors' own archives. Additionally, for governmental reports and other non-academic documents, searches were conducted through Google and websites of the WHO and two major international PA promotion networks: the GoPA and the Active Healthy Kids Global Alliance.

\section{Inclusion criteria}

To be included in the review publications had to meet the following criteria:

1. One of the aims of the publication was to analyse PA and/or SB policy or obesity, NCD prevention, sport for all/recreation, and/or other health-related policies that included an analysis of PA and/or SB;

2. The study analysed national-level policies. For federations and multi-state countries, only studies analysing the highest level governmental policies were taken into account (for example Australia and the USA). In the United Kingdom (UK), policy development can occur for all of the UK, as well as for individual home countries. Thus, policies were also included for Scotland, England, Wales, or Northern Ireland, for consistency with previous analyses of national $\mathrm{PA} / \mathrm{SB}$ policies globally [11, 32-34].
3. The policy analysis was focused on the process of policy development and/or content of policy;

4. The full publication or at least its abstract was available in English.

We excluded publications that: evaluated impact of policy changes on levels of $\mathrm{PA}$ or SB; evaluated public opinion and/or knowledge about $\mathrm{PA} / \mathrm{SB}$ policy/guidelines; analysed international, subnational (e.g. local, regional, territorial, provincial), or non-governmental PA/ SB policies/guidelines; focused on policy implementation; or provided general, non-country specific policy recommendations.

\section{Definition of policy}

In accordance with Colebatch [35] and Birkland [36], for the purpose of this study we defined public policy as 'a broad orientation,' 'an indication of normal practice,' 'a specific commitment', or 'a statement of values' [35] with the following attributes: (i) it is made by governments on the "public's" behalf; (ii) it is structured as a response to a problem and orientated towards a desired state or a goal to solve the problem; and (iii) it is implemented and interpreted by private and public actors who have various understandings of solutions and problems [36]. It should be noted that this definition does not represent authors' general view on how public policy should be defined. While some studies proposed more specific definitions of policy [11, 26, 37], we used this broad and inclusive definition simply because the aim of our scoping review was to capture all the various research related to PA and SB policy. In previous studies, national PA/SB guidelines were considered as a policy document [38] or a policy paper [39], an area of policy content [40] or an element of a successful policy approach [41, 42]. Some authors suggested, however, a clear distinction should be made between a policy (defined as a policy document) and PA and health guidelines or recommendations [11, 43, 44]. For the purpose of this review we considered national $\mathrm{PA} / \mathrm{SB}$ guidelines as an indicator of government policy, because the act of issuing national PA/SB guidelines indicates that the government (as their issuing body) has policy supportive of promoting PA and reducing SB. To be as inclusive as possible, in the current study we, therefore, included studies analysing national-level PA/SB guidelines formally adopted and/or published by the government. We acknowledge, however, that there is no consensus among the researchers on this matter and that our definition of national PA/SB guidelines as an indicator of government policy may not necessarily be applicable in future PA/SB studies.

\section{Definition of policy analysis}

No consensus has been achieved among researchers on what constitutes a policy analysis. Kustec Lipicer stated 
that synonyms for policy evaluation available in the literature are analysis, appraisal, assessment, adjudgement, judgement, examination, critique, review, inspection, measuring and grading of policy [45]. For the purpose of this study we considered the term policy analysis broadly and used it as a synonym for evaluation, assessment, and review of policy.

\section{Study selection and data extraction}

The study selection was conducted in July 2017, independently by two authors, BKP and GO, whilst a third author, ZP, resolved discrepancies between the study selections. Extraction and tabulation of data was done by one author (BKP). Two authors (BKP and ZP) independently checked for inconsistencies in the extracted data and revised the tables (Additional files 2, 3, 4 and 5). From every included study, we extracted data on its scope (national or international), number of covered countries, focus of the study (including type of the analysed policy, country, and specific target population), the period from which policies were analysed, summary of methods used to analyse policies, and main nationallevel and international-level findings.

\section{Categorisation of countries}

The World Bank's list of 218 economies from June 2017 was used as the list of countries/states/regions/economies [46]. As mentioned above, we included four UK's home nations separately, so the total number of countries encompassed in this review was 221. The authors are aware that some countries/states/regions/economies on the World Bank's list cannot be termed as "countries" because of disputable political and legal issues. However, for the purpose of brevity, we used the term country as an abbreviation for "countries/states/regions/economies" on the World Bank's list. The categorisation of the countries into four income groups: low income; lower middle income; upper middle income; and high income, as well as the division of countries into regions was also done using the World Bank's list. According to the list Europe and Central Asia constitute one region. To enable drawing conclusions about geographically more specific areas, we additionally divided Europe into four regions as defined by the Publications Office of the European Union (EU) as part of EuroVoc.

\section{Results}

\section{General findings}

In total, we screened 24,872 documents. Two hundred and three publications $[6,8,10-12,26,32-34,37-40$, 43, 44, 47-234] from 163 original studies met the selection criteria (Fig. 1). A list of all studies with a short description, including the year of publication, key focus, study period, and methods, is presented in Additional file 2. We extracted data from each of the 163 studies (some of which included a single country and

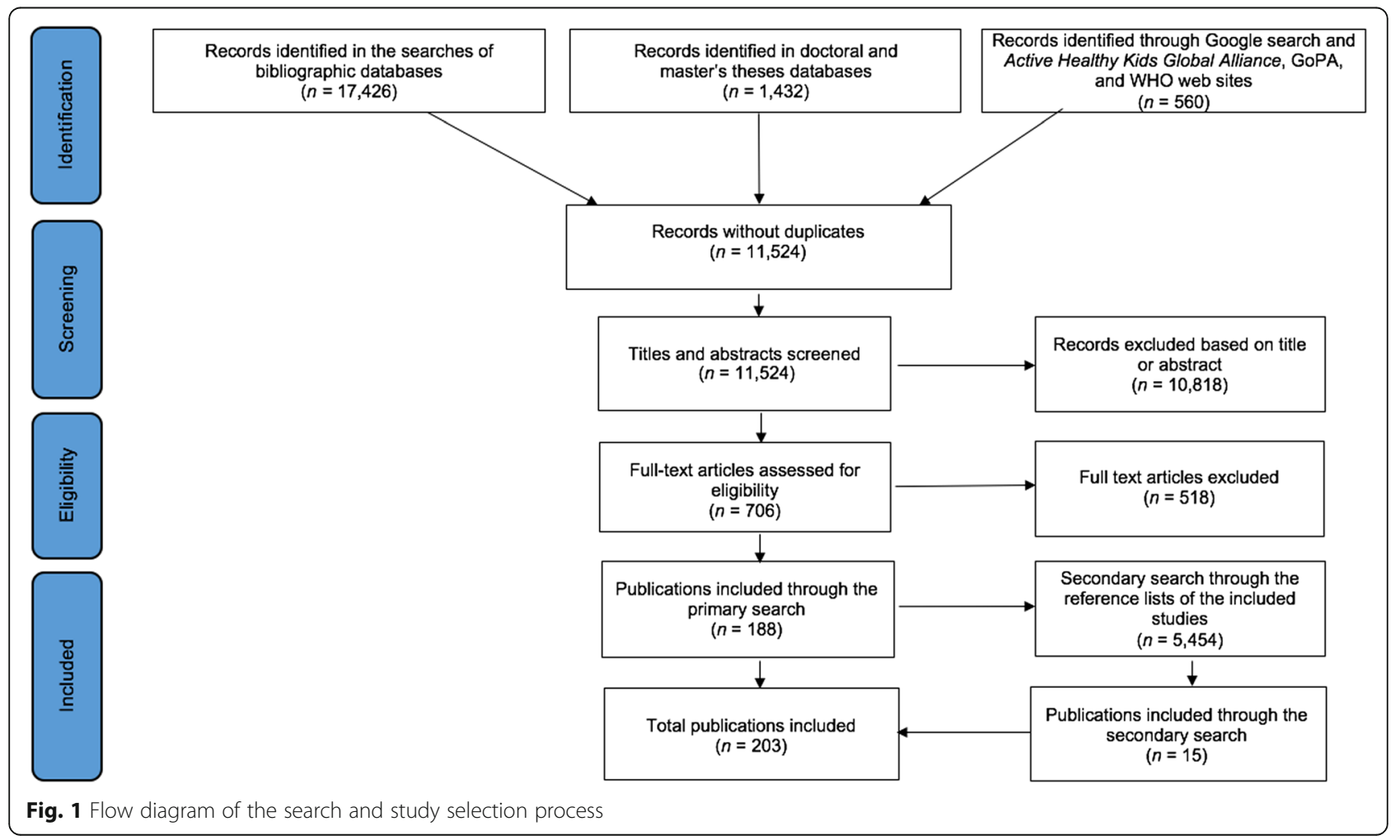


some of which included multiple countries) to create a breakdown of policy studies for each individual country. If a study included, for example, four countries, it is listed under each of these four countries separately in Additional file 3, creating 635 country-specific policy analyses in total. The full-texts of 12 academic publications were not in English but in Chinese $(n=2)$, Czech $(n=2)$, French $(n=2)$, Korean $(n=1)$, Portuguese $(n=$ $2)$, and Spanish $(n=3)$. These publications were translated into English for data extraction purposes. The selected studies investigated PA and/or SB policies in 168 out of 221 countries worldwide. From these studies, seven were focused exclusively on PA/SB guidelines. The large majority of studies (72\%) focused only on one country, whilst the remaining $28 \%$ of studies compared or presented an overview of two or more countries. The key findings of the included studies for each of the 168 countries separately are summarised in Additional file 3, whilst international (non-country specific) findings are presented in Additional file 4.

Active Healthy Kids Report Cards for Children and Youth or published articles based on the report card data comprised $40 \%$ of all the included studies. The Report Cards are developed under the Active Healthy Kids Global Alliance, a network of researchers, stakeholders, and health professionals [235]. This large international project is based on a Canadian initiative that now includes 38 countries [34]. Some countries like Canada, publish their Report Cards annually, but most other countries published them biennially. The Report Cards aim to assess how each country is performing in promoting and facilitating PA opportunities for children and youth [236]. The common nine indicators incorporated in most countries' report cards are: (i) overall levels of PA; (ii) organized sport and PA; (iii) active play; (iv) active transportation; (v) SB; (vi) support from family and peers; (vii) school environment; (viii) community and the built environment; and (ix) government strategies and investments [237]. A group of experts from each country responsible for the development of the report card assesses performance against each of the indicators and provides usually alphabetical grades for each indicator (from A to F and INC as incomplete). The key findings from the last indicator, that is, Government's Strategies and Investments, and the respective grade country experts assigned to their country are summarised in Additional file 3, whilst the joint findings and comparison of grades from the 2014 report cards [33] and the 2016 report cards [34] are summarised in Additional file 4.

A major contribution to worldwide PA policy monitoring was also provided by the GoPA $[32,176]$. GoPA is a Council of the International Society of Physical Activity and Health (ISPAH), and was established to measure global progress in the area of PA research, surveillance, and policy [176]. GoPA collected data for 217 countries and confirmed data accuracy for 139 countries. For 53 countries, in our overall results, the only data included in the current review were from the GoPA country cards. GoPA developed PA country cards with six key indicators reported by key country informants: (i) general information on the country (including the Capital city, number of inhabitants, and life expectancy); (ii) PA prevalence among adults; (iii) health burden of insufficient PA (not meeting PA guidelines); (iv) existence of a national PA plan (yes/no); (v) information about PA surveillance (presence, year); and (vi) a research output metric based on bibliographical assessment of published peer reviewed journal articles on PA. The fourth indicator on the availability of a national or subnational PA plan was extracted for the purpose of this review. GoPA provided descriptive data on PA policy for 139 countries, which constitutes $22 \%$ of all findings identified in this review.

We found some discrepancies in findings, especially for those countries that were analysed by multiple independent studies (see Additional file 3). Some of the possible reasons include: authors' subjectivity in assessment of the data; different methods used for analysing and obtaining the data; different interviewees involved in the study; and actual change in policy that occurred in the periods between studies.

\section{Findings by regions and economic standard}

Sixty-nine percent $(n=438)$ of 635 country-specific policy analyses focused on high-income countries, out of which $63 \%(n=277)$ related to European Union (EU) member states (Fig. 2). No studies were identified for ten out of 81 high-income countries: the Bahamas, the British Virgin Islands, Channel Islands, Curaçao, Gibraltar, Isle of Man, Lichtenstein, Saint Maarten (Dutch part), Taiwan, and Turks and Caicos Islands. For 23 high-income countries only one country-specific policy analysis was found; with most of those findings arising from the GoPA's 1st Physical Activity Almanac [32]. Middle-income countries were investigated in $29 \%$ of country-specific policy analyses, and low-income countries in only $2 \%$. For 21 out of a total of 31 low-income countries globally, and 22 out of 109 middle-income countries, no PA/SB studies were found (Fig. 3). The most eSxtensive policy review for low- and middle-income countries was performed by Lachat et al. [140]. They assessed the existence and content of governmental NCD, health, or nutrition policy documents from 83 WHO member states. However, the paper includes brief findings related to PA policies for only 35 countries. For $7 \%$ of all low- and middle-income countries presented in the current review - namely Cambodia, Djibouti, Jamaica, Madagascar, Mauritius, 


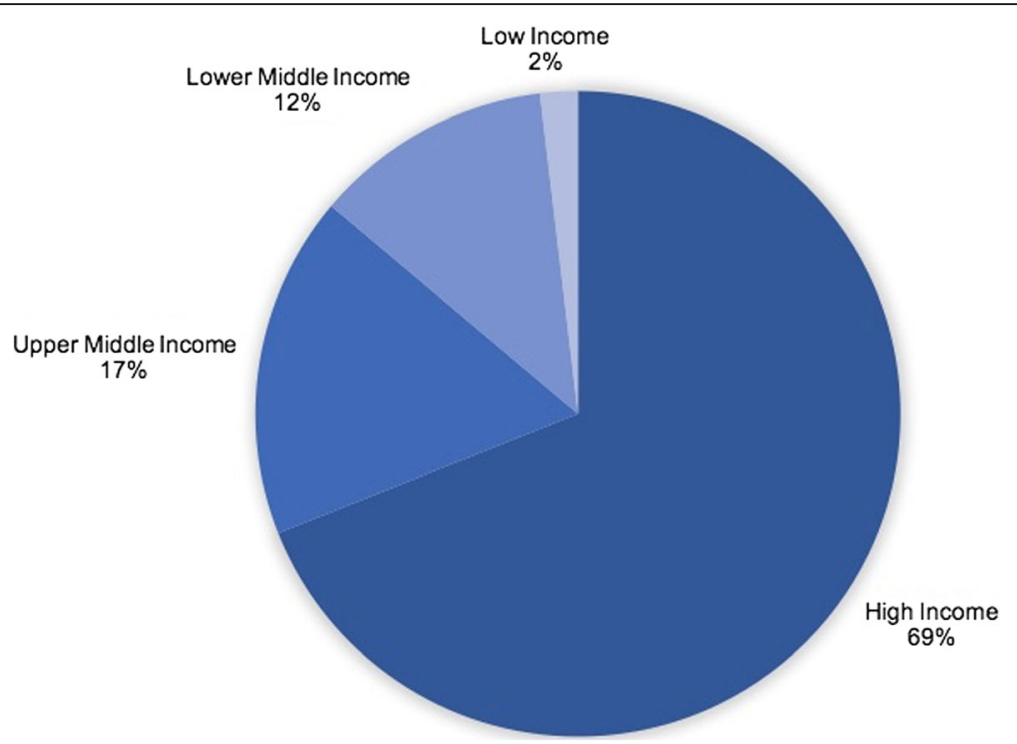

Fig. 2 Distribution of PA/SB policy research across countries by economic standard

Niger, and the Philippines - findings on PA/SB policy were only available from the Lachat et al. [140] paper.

For 63 countries, only descriptive data, stating the existence and/or name of a policy document was found. More detailed analysis of PA related policies were available for Australia [6, 187], Brazil [96, 187], Canada [95, 187, 219], Chile [186], England [40], Finland [10, 39, 84, 187], France [82, 172], Italy [84], Mexico [153], the Netherlands [187], New Zealand [187], Norway [84], Portugal [84], Scotland [187], Slovenia [84], Switzerland [84, 187], and the USA [113]. Analyses of sport or leisure policies that contain substantial information on PA policies were available for Canada [76], Chile [81], China [146, 203],
Cameroon [93], Czech Republic [139], England [76, 196], Germany [76], Malaysia [66], the Netherlands [200], New Zealand [66, 168], Norway [76, 195], Portugal [94], the UK [112, 156], and Vanuatu [135] (Additional file 3).

Only $22 \%$ of included studies mentioned SB as part of policy, and just one recent study analysed policies related to SB independently of PA policies [38]. Specifically, mentions of SB related policies/guidelines were found in research for Australia [190], Belgium [38], Canada [33], Finland [39], Hong Kong [124], Ireland [118], Iceland [127], Malta [127], New Zealand [149], Russia [127], Switzerland [127], and Sweden [38] (Additional file 3).

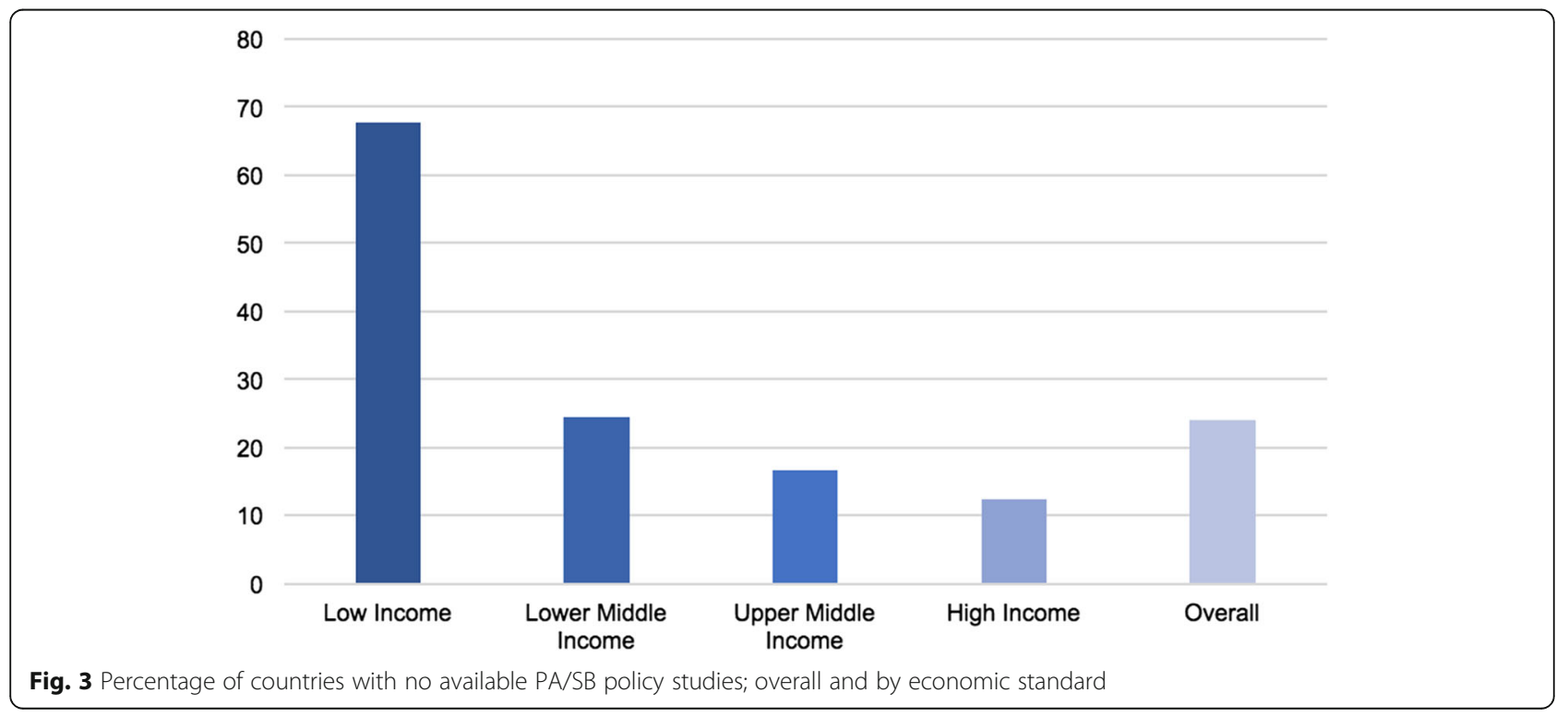


The distribution of PA/SB policy research across countries is presented in Fig. 4. England, Canada, and Finland have been researched the most. Brazil and Mexico were the most represented countries from the Latin American and Caribbean region. In this region, no data were found for Belize, El Salvador, French Guiana, Honduras, Panama, and Suriname. From Sub-Saharan Africa, the most data were available for South Africa. However, Africa in general, both North and Sub-Saharan is the continent with least research found. From the Middle East, Yemen was the only country for which data were not found. The majority of research (55\%) concerned European countries. For England, Finland, the Netherlands, and Scotland we found 15 or more studies. Most of the research was in regard to countries in Northern and Western Europe, with on average ten studies per country. Southern Europe had on average five studies per country and Eastern Europe four. From East Asia and Pacific region most data were found for Australia. China was the most researched Asian country.

\section{Conceptualisation of policy, frameworks and methods}

A definition of policy, public policy, health policy, and/ or PA policy was found in $13 \%$ of all included publications. A list of all definitions found in the publications is provided in Additional file $5[6,8,11,12,16,26,37,39$, $40,43,44,54-56,62,86,92,95,103,113,129,140,153$, $168,171,185,187,218,228,229,231,238-245]$. The most commonly used definition of PA policy was originally proposed by Bull et al. [26]. The conceptualisation of policy varied across studies and often even within the same study. Only $15 \%$ of the included studies used a conceptual or theoretical framework. Kingdon's Multiple Streams framework was used in four studies [116, 154, 169, 171]. Elite theory [203], multilevel model of PA promotion [185], figurational sociology [200], institutional change theory [108], the Theoretical Domains Framework, and the Behaviour Change Techniques Taxonomy [39] are among the other frameworks that were used. All four selected doctoral dissertations were based on conceptual/theoretical frameworks $[66,107,168$, 219].

The included studies used a variety of methods for data collection and analysis of PA/SB policy (Additional file 2). All studies relied on some form of literature review. Expert review was used in $46 \%$ of the studies. Content analysis of documents was used in $6 \%$ of the studies. Interviews (mainly semi-structured) were used in $9 \%$ of the studies. Some studies combined both content analysis of interviews and content analysis of documents [115-117, 139, 154]. Interviews were combined with focus groups in two studies $[139,185]$, and a focus group was combined with content analysis of documents in one study [38]. Discourse analysis was used in $2 \%$ of the studies [73, 107, 141, 168], among which half also used interviews as their research method [107, 168]. A case study design was employed in $6 \%$ of the studies. A number of studies did not clearly specify their research methods.

\section{Discussion}

This is the first systematic scoping review of global PA/ $\mathrm{SB}$ policy research. We found that PA policy research is much more developed than it was previously considered.

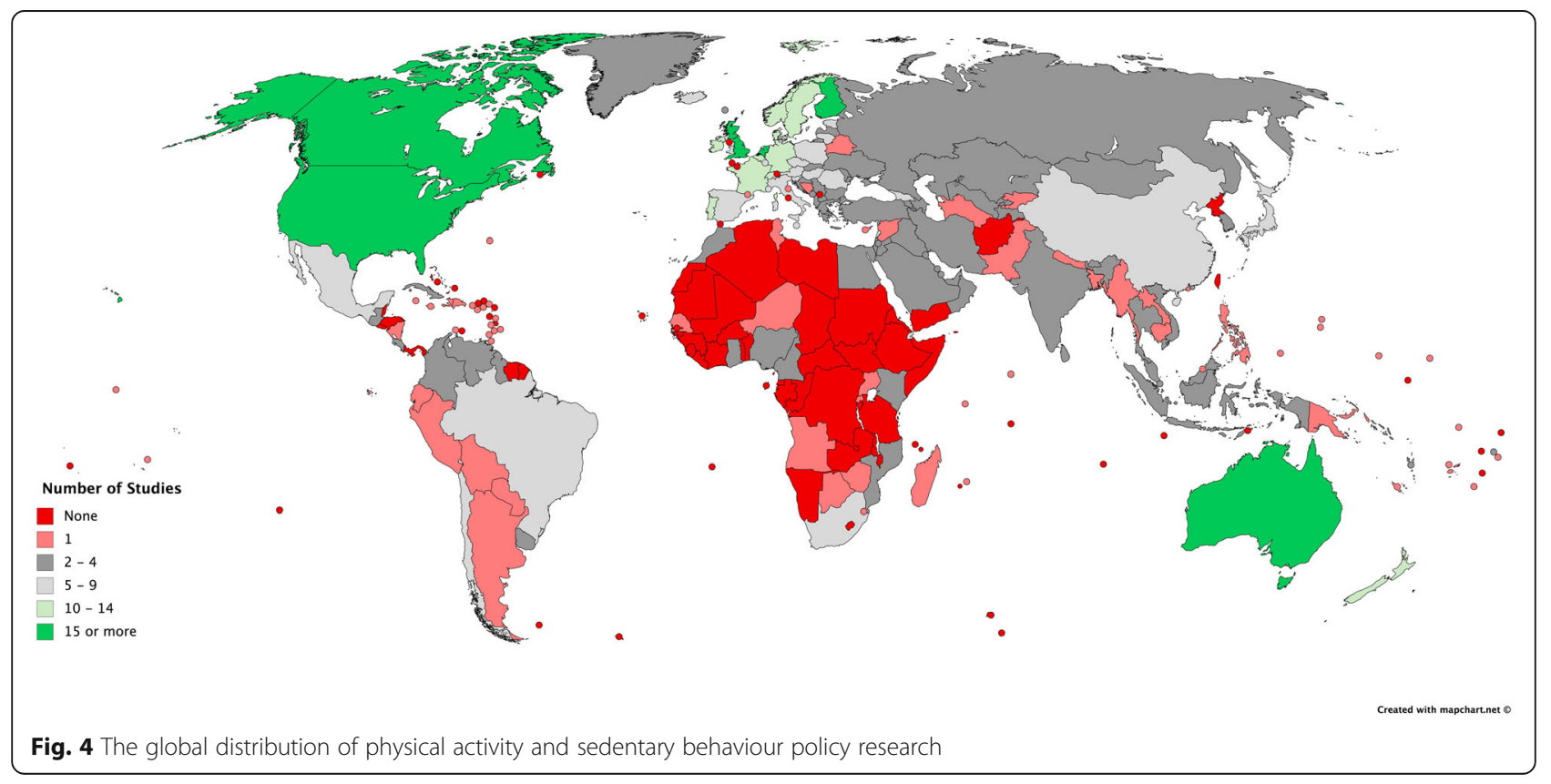


However, there are few examples of policies that included SB. Three key issues were identified that should be addressed in further research: (i) there is a lack of $\mathrm{PA} / \mathrm{SB}$ policy research in low- and middle-income countries, which is an important limitation of the current body of evidence; (ii) the definition of policy varied significantly across studies, and most studies did not rely on any theoretical framework, which may impede crossstudy comparisons; and (iii) studies have used a variety of methods to collect data and analyse policy, which may also cause problems with comparability. Each of these future research directions are discussed further below.

Different studies largely differed in their focus and aims. Accordingly, the depth of analysis varied significantly across studies. The studies that mainly focused on monitoring policies, such as Ramirez Varela et al. [32], may be useful for providing a broad picture on PA policies globally. Studies that reviewed documents and their content in one region, such as Ceccarelli [90] and Kahlmeier et al. [127], can serve as a comparative overview of best practices and a good starting point for further research and more elaborated analyses of national policy. Detailed comparative studies on policies in a few countries, such as Bergsgard et al. [76], may be useful for understanding why some countries are more successful in PA promotion than others. Studies that critically assess PA policy in a single country, for example Milton and Bauman study for England [40] and Craig for Canada [95], may be useful for researchers and policy makers interested in the country's policy situation and possible ways of improving it. Studies focusing on detailed assessment of one policy document, such as Pérez-Escamilla [167], may provide grounds for improving the documents and may be useful for informing the development of similar policy documents in other countries.

\section{Towards more research in low and middle-income countries}

Most research was conducted to analyse PA/SB policies in high-income countries, whilst low- and middle-income countries are significantly underrepresented within PA/SB policy research. Most available findings for low- and middle-income countries are provided in the GoPA's 1st Physical Activity Almanac; hence this publication can be considered an important contribution to the development of PA policy research in these countries. For 17 high-income countries and 36 low- and middle-income countries, the only data we found were from GoPA country cards. Thus the country cards might be considered an important starting point for guiding PA policy developments in countries around the world. However, they merely include a statement about the availability (Yes/No) of the national or subnational PA plan $(n=47)$, the inclusion of PA within a broader NCD policy $(n=16)$, and the name of the available policy document $(n=76)$ as opposed to a detailed analysis of PA/SB policy status.

Another important study providing data for low- and middle-income was a review conducted by Lachat et al. [140], where PA/SB policies were analysed in the broader context of NCD prevention, together with nutrition-related policies. However, due to the fact that this study had a wider scope, only limited data were provided specifically on PA/SB policy. Policy actions and targets related to PA promotion were extracted from the respective documents, so unlike GoPA's country cards, this study reports on some specific content of the policy documents. However, this review [140] provided no references for the reviewed policy document for Costa Rica, Madagascar, Guatemala, Solomon Islands, and Djibouti, which may limit the usability of their findings in future research on PA/SB policies in these countries. Another limitation of this review is that, while reporting on whether inactive lifestyle was discussed within policy documents, it did not distinguish between SB (nowadays defined as prolonged sitting) and inactive lifestyle (traditionally defined as lack of PA). This may cause confusion between the two concepts that the current epidemiological research clearly differentiates [25]. Clearly, more studies comprehensively reviewing PA and SB policies in low- and middleincome countries are needed.

General information on national PA/SB policies can also be found in studies from other sectors, for example NCD prevention [28, 246-249]. However, the depth of information they provide on PA/SB policies is often limited, as these policies are not in their main focus.

Furthermore, for large high-income countries, such as Canada, USA and Australia, a number of studies that analysed subnational (that is state, territorial, provincial, municipal, regional or local PA policies) were identified during the study selection process. For example, in the USA, a number of studies related to school district PA policies were found. Such studies may provide very useful information for PA/SB policy development at a local level and should, therefore, continue to be conducted in countries of both higher and lower economic standard. A separate scoping review of subnational PA/SB policy research is warranted as a systematic assessment of studies on this topic was beyond the scope of the current paper.

Taking into account that, for 53 countries around the world, no PA/SB policy studies were found, continued efforts in PA/SB policy development and research are needed. However, this might also be due to language restrictions, as this review included only studies with titles 
and abstracts in the English language. Further research should pay special attention to the low- and middle-income countries and those high-income countries with little or no available data.

\section{Towards a standardised conceptualisation of PA/SB related policies}

Policy was differently conceptualised across different studies. In 2006, Schmid et al. wrote that "public health policy around PA remains poorly defined and developed" [16]. Given that only $10 \%$ of the selected studies were published before the Schmid et al. paper, the statement about the poor development of PA policy may not be true anymore. However, taking into account the issues with defining and conceptualising PA and SB policy across the studies included in this review, the Schmid et al. statement about the generally poor definition of PA policy remains valid. Schmid et al. conceptualised policy, reflecting political and social commitment, at three levels: (i) formal written codes, regulations or decisions holding legal authority; (ii) written standards that guide choices; and (iii) unwritten social norms that impact behaviours [16]. Among the currently reviewed studies that provided an operational definition of policy, the vast majority conceptualised it within the Schmid et al.'s first level. Many studies relied on the definition of policy provided by Daugbjerg et al. that conceptualises 'policy' as a 'policy document', that is a "written document that contains strategies and priorities, defines goals and objectives, and is issued by a part of the administration" [11]. This definition was later used as the working definition in the WHO and the European Commission in their joint reports of the National Information Focal Points meetings [228]. Rütten et al. for example stated that their approach is grounded on a broader definition of policy than the one proposed by the WHO, which also includes informal institutional procedures, arrangements and rationales for action on health- related issues [185]. The most often used definition of PA policy was proposed by Bull et al., which defines it as a "formal statement that defines physical activity as a priority area, states specific population targets and provides a specific plan or framework for action" [26]. In most cases, studies focused only on public sector policies, that is, "governmental statements", whilst somewhat less often they also included written statements of NGOs, international organisations, and professional bodies. Some studies, such as Christiansen et al. and Daugbjerg et al., clearly distinguished between policy and other documents such as strategies, action plans, and guidelines [11, 44]. These two studies as well as Al-Bahlani and Mabry [62] made a distinction between policies and legislation. Unlike, for example Coenen et al. [38] who under the category "policy documents" included guidelines, legislation, directives, and codes of practices. Seppälä et al. [39] under "policy papers" also included guidelines, good practice guides, strategies, and action plans. A number of studies did not clearly differentiate between interventions, policies, and policy actions. Some studies, such as Milton and Bauman [40] conceptualised PA policy more comprehensively and considered national recommendations on PA levels, national targets and goals related to PA, public education on PA, and PA surveillance and monitoring as key aspects of national PA policy, whilst others, such as Pate et al. [37] defined it more narrowly as formal written documents providing guidelines on public PA promotion.

Various understandings and conceptualisations of PA policy within and between studies may create confusion within the field and negatively affect comparability of findings, but may also be part of an evolutionary process of reaching a consensus on what PA policy is. However, political scientists have agreed there is likely never to be a universal definition of policy. Policy is a flexible concept used differently in different contexts and on different occasions. It is a "continuing process of social action and interaction" and there are a lot of different ways in which people perceive or perform policy [35]. Using the term "policy" in different ways across different contexts is not necessarily a problem [35]. However, we believe defining it within every specific academic discourse can be beneficial and would significantly contribute to the reduction of analytical weaknesses present in some PA/ SB policy studies that, by not providing a clear operational definition of policy, often fail to properly define their object of policy analysis.

The conceptualisation of PA/SB policy depends also on the definition of PA and SB. Even though scientific consensus seems to have been achieved [25], PA is still often confused with sport, physical fitness, and exercise. The inconsistency regarding the definition of SB is even larger, probably because SB research is a much younger field than PA epidemiology. The interchangeable use of the terms 'physical inactivity', 'sedentary lifestyle,' 'screen-time', and 'sedentary behaviour' is still very common among scholars [21]. The Sedentary Behaviour Research Network (SBRN) initiated the Terminology Consensus Project and suggested definitions of several terms related to SB [25]; yet definitions of some common terms, such as "sedentary lifestyle", have still not been clarified [25].

Finally, only $15 \%$ of the PA/SB policy studies relied on theoretical or conceptual frameworks to support their analyses. It is evident that PA/SB policy research should be more grounded in existing frameworks. For example, in 2006, Schmid et al. developed the Framework for PA Policy Research. Although this framework was mentioned in several studies $[8,11,44,103,171,185,218$, $219]$, only two studies based its content analysis grid on 
this framework [11, 44]. Using some of many available theories, frameworks, methods, and concepts available from political science and other established disciplines could positively contribute to the further improvement and standardisation of $\mathrm{PA} / \mathrm{SB}$ policy research. It should be noted, however, that the diversity of approaches and definitions may sometimes be considered desirable, especially in young fields of research. Advancing to standardisation too soon might hinder the development and exploration of some potentially useful approaches.

\section{Towards a standardised policy analysis}

The so-called "policy science" and its main component, policy analysis, have been developing since the 1950s when Harold Lasswell's seminal book The Policy Sciences - Recent Developments in Scope and Method was published [250]. However, due to the lack of a universally accepted definition of policy, there is also no universally accepted method to perform policy analysis. This review revealed that the methods used for PA/SB policy research are far from being standardised and that the form of research outputs in this area largely depended on individual approaches. The sage words of the authors of The Australian Policy Handbook: "Policy analysis is a balance between art and science." [251] can, therefore, also be applied to research analysing PA/SB policies. While some claim there is no difference between policy analysis, policy assessment, and policy evaluation, some made guidelines on how each one of these should be performed and differentiated from the others [252, 253]. Policy analysis as a craft "draws on intuition as much as on method" [254]. Considering that PA/SB policy research is at least 40 years younger than "policy science", it is understandable that it still draws more on intuition than on method. This notion is grounded in the fact that most of the studies included in this review did not rely on specific, conventional policy research methods but usually on narrative literature reviews and expert reviews.

The challenges in policy analysis were clearly outlined in some reviewed studies. For example, the Active Healthy Kids Report Card's indicator titled Government Strategies and Investments was assessed against three benchmarks: (i) "evidence of leadership and commitment in providing physical activity opportunities for all children and youth"; (ii) "allocated funds and resources for the implementation of physical activity promotion strategies and initiatives for all children and youth"; and (iii) "demonstrated progress through the key stages of public policy making (i.e., policy agenda, policy formation, policy implementation, policy evaluation and decisions about the future)" [34]. However, this indicator has been reported as "difficult to grade" [33]. In the first comparative 'Global Matrix' of grades from 2014, one- third of the countries did not grade this indicator and marked it as incomplete [33]. In the second 'Global Matrix' it was reported that only six out of 38 countries marked this indicator as incomplete [34]. Even though the number of countries that assigned grades was higher in the second matrix than in the first one, several Report Cards stated that this indicator is one of the hardest to grade. Some of the reported reasons were: a lack of agreed assessment criteria [147, 149] or specific international recommendations [215]; no well-founded and clear criteria or benchmarks to outline which amount of investments is acceptable or which policy is effective [87]; and the perception that the Report Cards are not fit for policy evaluation purposes [121]. In the results from Qatar's Report Card, it was stated that the grade was assigned "as in most countries" based on the "presence" of national investments and strategies related to children and youth's health and PA [63]. This may not be considered the most informative approach to PA/SB policy analysis.

To support standardised analysis of national policy approaches to PA, the HEPA Europe expert group developed a comprehensive instrument entitled Health Enhancing Physical Activity Policy Audit Tool (HEPA PAT) [30, 85], structured around 17 key elements for a successful national approach to PA promotion. Prior to its development, there was no "standardised instrument to capture the relevant policy information in a standardised way or to collate more in-depth data" [30]. HEPA PAT is one of the rare tools that, in addition to PA, also informs on SB policies. The protocol recommends that PAT is completed using a collaborative process and involving multiple sectors. It suggests that responses from all relevant sectors are collected and reviewed collectively and that the process of completion itself can support and strengthen policy development. However, the early experiences of countries developing the HEPA PAT found that between three and 6 months are needed to complete the whole process [42] which is probably the main reason why since its development it has only been used in three other studies [172, 232, 255]. There are, however, promising ongoing initiatives that will likely ensure the implementation of HEPA PAT in more countries internationally. It is also important to mention that the primary purpose of HEPA PAT is limited to policy audit and therefore, it cannot be used for the policy assessment (or grading as in the case of the Active Healthy Kids Report Cards). There seems to be a need for the development of a tool which would allow for rating or assessment of the success and progress of national policies related to PA/SB [30]. More coordinated work on a standardised approach to international analysis of $\mathrm{PA} / \mathrm{SB}$ policies would significantly contribute to the further development of this research area. 


\section{Strengths and limitations of the review}

The key strengths of the current review include: (i) the search was conducted through a range of bibliographic databases, reference lists of included articles, and relevant websites, which reduced the likelihood of missing relevant publications; (ii) we used an inclusive search syntax and broad eligibility criteria that allowed us to identify and include relevant studies on a wide range of PA/SB policy topics; (iii) the assessment of eligibility of studies was done in duplicate, which reduced the likelihood of bias in study selection; (iv) we clearly stated the definitions of policy and policy analysis used for the purpose of this review; and (v) full-texts of 12 publications were translated from their original languages into English to allow for data extraction.

This review is subject to some limitations. Firstly, although the literature search was done with no language restrictions, we were able to include only publications with titles and abstracts in English. This may have resulted in the omission of some relevant publications. It should be noted, however, that we included 12 publications with full-texts in languages other than English. Secondly, we did not conduct a formal assessment of study and evidence quality. This was not possible to be done in a systematic fashion, because the included studies were conducted using a wide variety of study designs and methods. Nevertheless, based on the extracted data, we provided a general assessment of the overall completeness of evidence. Finally, we did not conduct an in-depth analysis of $\mathrm{PA} / \mathrm{SB}$ policies for each specific country. Although such an analysis would be of great value for future research and policy initiatives, it was beyond the scope of this review. Nevertheless, we summarised findings of the included studies for a total of 168 countries.

\section{Conclusion}

The results of this systematic scoping review show that PA policy research is much more developed than it was considered several years ago. Research around SB policies is still in its infancy, but it seems to have experienced some positive progress in the last few years. There are still a large number of countries with no or very little research on PA/SB policy, particularly among those with low or middle income. Increased efforts should be made to include such countries into academic discussion on PA/SB policy. Future PA/SB policy studies should also aim towards a clearer conceptualisation of policy, greater reliance on existing theoretical frameworks, and the use and further development of standardised methods for $\mathrm{PA} / \mathrm{SB}$ policy analysis.

\section{Additional files}

Additional file 1: Full search syntaxes used for each database. (PDF 90 kb)

Additional file 2: Description of studies analysing indicators,

development, and content of national-level physical activity and sedentary behaviour policies. (PDF $434 \mathrm{~kb}$ )

Additional file 3: Summary results of studies analysing indicators, development, and content of national-level physical activity and sedentary behaviour policies: country-specific findings. (PDF 836 kb)

Additional file 4: Summary results of studies analysing indicators, development, and content of national-level physical activity and sedentary behaviour policies: international findings. (PDF $138 \mathrm{~kb}$ )

Additional file 5: Definitions of policy in general, public policy, physical activity policy, health policy, and policy document included in studies analysing indicators, development, and content of national-level physical activity and sedentary behaviour policies. (PDF 114 kb)

\section{Abbreviations}

CDC: Centers for Disease Control and Prevention; EU: European Union; GoPA: Global Observatory for Physical Activity; HEPA PAT: Health-enhancing physical activity policy audit tool; HEPA: Health-enhancing physical activity; NCD: Noncommunicable disease; NGO: Nongovernmental organisation; PA: Physical activity; SB: Sedentary behaviour; UK: United Kingdom; UN: United Nations; USA: United States of America; WHO: World Health Organization

\section{Acknowledgments}

This article is a part of the PhD project of the first author, BKP, supervised by $\mathrm{KM}, \mathrm{SJHB}$, and ZP (principal supervisor). The protocol for this review was described in the Candidature Proposal of BKP, approved on 22/11/2017 by the Graduate Research Centre at the Victoria University, Melbourne, Australia.

\section{Funding}

Not applicable.

\section{Availability of data and materials}

The summary of reviewed articles is available in Figures and Additional files.

\section{Authors' contributions}

BKP and ZP conceived the idea for the review. BKP, ZP, SJHB, and KM conceptualised the review. BKP took the lead in writing the study protocol. BKP and ZP designed the systematic search strategies. BKP and GOS conducted the study selection. BKP extracted, tabulated, and analysed the data. BKP and ZP checked for inconsistencies in the extracted data and revised the tables. BKP drafted the initial manuscript. $Z P, K M, S B, G O S, A B, F B$, SK, and MP contributed to writing the manuscript. All authors read and approved the final manuscript.

Ethics approval and consent to participate

Not applicable.

Consent for publication

Not applicable.

\section{Competing interests}

The authors declare that they have no competing interests.

\section{Publisher's Note}

Springer Nature remains neutral with regard to jurisdictional claims in published maps and institutional affiliations.

\section{Author details}

${ }^{1}$ Institute for Health and Sport, Victoria University, Ballarat Road, Footscray, Melbourne, VIC 3001, Australia. ${ }^{2}$ Norwich Medical School, University of East Anglia, Norwich Research Park, Norwich, Norfolk NR4 7TJ, UK. ${ }^{3}$ Institute for Resilient Regions, University of Southern Queensland, 37 Sinnathamby Boulevard, Springfield Central, QLD 4300, Australia. ${ }^{4}$ Sydney School of Public Health, University of Sydney, Camperdown, Sydney, NSW, Australia. 
${ }^{5}$ Surveillance and Population Based Prevention, Prevention of Noncommunicable Disease, World Health Organization, Geneva 27, Switzerland. ${ }^{6}$ Faculty of Human Science, The University of Western Australia, Perth, Australia. ${ }^{7}$ Epidemiology, Biostatistics, and Prevention Institute, University of Zürich, Hirschengraben 84, 8001 Zürich, Switzerland. ${ }^{8}$ San Diego School of Medicine, University of California, 9500 Gilman Drive, San Diego, USA.

\section{Received: 8 July 2018 Accepted: 25 October 2018} Published online: 28 November 2018

\section{References}

1. World Health Organization. Noncommunicable diseases. [http://www.who. int/mediacentre/factsheets/fs355/en/]. Accessed 2 Feb 2018.

2. World Health Organization. Physical Activity Fact sheet [http://www.who.int/ mediacentre/factsheets/fs385/en/]. Accessed 2 Feb 2018.

3. Rezende LFM, Sá TH, Mielke GI, Viscondi JYK, Rey-López JP, Garcia LMT. Allcause mortality attributable to sitting time: analysis of 54 countries worldwide. Am J Prev Med. 2016;51(2):253-63.

4. Lee I-M, Shiroma EJ, Lobelo F, Puska P, Blair SN, Katzmarzyk PT, Group LPASW. Effect of physical inactivity on major non-communicable diseases worldwide: an analysis of burden of disease and life expectancy. Lancet. 2012;380(9838):219-29.

5. Ding D, Lawson KD, Kolbe-Alexander TL, Finkelstein EA, Katzmarzyk PT, van Mechelen W, Pratt M, Committee LPASE. The economic burden of physical inactivity: a global analysis of major non-communicable diseases. Lancet. 2016;388(10051):1311-24

6. Bellew B, Schöeppe S, Bull FC, Bauman A. The rise and fall of Australian physical activity policy 1996-2006: a national review framed in an international context. Aust New Zealand Health Policy. 2008:5:18.

7. Sallis J, Cervero R, Ascher W, Henderson K, Kraft K, Kerr J. An ecological approach to creating active living communities. Annu Rev Public Health. 2006:27:297-322.

8. Bellew B, Bauman A, Martin B, Bull F, Matsudo V. Public policy actions needed to promote physical activity. Curr Cardiovasc Risk Rep. 2011;5(4): 340-9.

9. World Health Organization. Physical activity for health, More active people for a healthier world: draft global action plan on physical activity 20182030. 2017.

10. Vuori I, Lankenau B, Pratt M. Physical activity policy and program development: the experience in Finland. Public Health Rep. 2004;119(3): 331-45.

11. Daugbjerg SB, Kahlmeier S, Racioppi F, Martin-Diener E, Martin B, Oja P, Bull F. Promotion of physical activity in the European region: content analysis of 27 national policy documents. J Phys Act Health. 2009;6(6):805-17.

12. World Health Organization. Review of physical activity promotion policy development and legislation in European Union Member States. Copenhagen: World Health Organization, Regional Office for Europe; 2010.

13. Varela AR, Pratt M, Harris JE, Lecy J, Salvo D, Brownson R, Hallal P. Mapping the historical development of physical activity and health research: a structured literature review and citation network analysis. Prev Med. 2018; 111:466-72.

14. Morris JN, Heady J, Raffle P, Roberts C, Parks J. Coronary heart-disease and physical activity of work. Lancet. 1953;262(6796):1111-20.

15. Breton $\mathrm{E}$, De Leeuw $\mathrm{E}$. Theories of the policy process in health promotion research: a review. Health Promot Int. 2010;26(1):82-90

16. Schmid TL, Pratt M, Witmer L. A framework for physical activity policy research. J Phys Act Health. 2006;3(Suppl 1):S20-9.

17. Kohl HW 3rd, Craig CL, Lambert EV, Inoue S, Alkandari JR, Leetongin G, Kahlmeier S, Group LPASW. The pandemic of physical inactivity: global action for public health. Lancet. 2012;380(9838):294-305.

18. Shephard RJ, Lankenau B, Pratt M, Neiman A, Puska P, Benaziza H, Bauman A. Physical Activity Policy Development: a synopsis of the WHO/CDC Consultation, September 29 through October 2, 2002, Atlanta, Georgia. Public Health Rep. 2004;119(3):346-51.

19. World Health Organization. Global strategy on diet, physical activity and health. Geneva: Switzerland World Health Organization; 2004

20. Owen N, Bauman A, Brown W. Too much sitting: a novel and important predictor of chronic disease risk? Br J Sports Med. 2009;43(2):81-3.

21. Pedišić Ž. Measurement issues and poor adjustments for physical activity and sleep undermine sedentary behaviour research - the focus should shift to the balance between sleep, sedentary behaviour, standing and activity. Kinesiology. 2014;46(1):135-46.

22. Pedišić Ž, Dumuid D, Olds T. Integrating sleep, sedentary behaviour, and physical activity research in the emerging field of time-use epidemiology: definitions, concepts, statistical methods, theoretical framework, and future directions. Kinesiology. 2017;49(2):135-45.

23. Ekelund U, Steene-Johannessen J, Brown WJ, Fagerland MW, Owen N, Powell KE, Bauman A, Lee I-M, Series LPA, Group LSBW. Does physical activity attenuate, or even eliminate, the detrimental association of sitting time with mortality? A harmonised meta-analysis of data from more than 1 million men and women. Lancet. 2016;388(10051):1302-10.

24. Dumuid D, Stanford TE, Martin-Fernández J-A, Pedišić Ž, Maher CA, Lewis LK, Hron K, Katzmarzyk PT, Chaput J-P, Fogelholm M. Compositional data analysis for physical activity, sedentary time and sleep research. Stat Methods Med Res. 2017. https://doi.org/10.1177/0962280217710835.

25. Tremblay MS, Aubert S, Barnes JD, Saunders TJ, Carson V, Latimer-Cheung AE, Chastin SFM, Altenburg TM, Chinapaw MJM, Aminian S, et al. Sedentary behavior research network (SBRN) - terminology consensus project process and outcome. Int J Behav Nutr Phys Act. 2017:14:75.

26. Bull F, Bellew B, Schoeppe S, Bauman A. Developments in National Physical Activity Policy: an international review and recommendations towards better practice. J Sci Med Sport. 2004;7(1):93-104.

27. Sallis JF, Bull F, Guthold R, Heath GW, Inoue S, Kelly P, Oyeyemi AL, Perez LG, Richards J, Hallal PC. Progress in physical activity over the Olympic quadrennium. Lancet. 2016;388(10051):1325-36.

28. World Health Organization. Assessing national capacity for the prevention and control of noncommunicable diseases. Report of the 2015 global survey. Geneva: World Health Organization; 2016.

29. Walt G, Gilson L. Reforming the health sector in developing countries: the central role of policy analysis. Health Policy Plan. 1994;9(4):353-70.

30. Bull F, Milton K, Kahlmeier S. National policy on physical activity: the development of a policy audit tool. J Phys Act Health. 2014;11(2):233-40.

31. Rütten A, Schow D, Breda J, Galea G, Kahlmeier S, Oppert J, Ploeg H, Mechelen $\mathrm{W}$. Three types of scientific evidence to inform physical activity policy: results from a comparative scoping review. Int J Public Health. 2016; 61(5):553-63.

32. Ramirez Varela A, Pratt M, Borges C, Hallal P. 1st Physical Activity Almanac: the Global Observatory for Physical Activity - GoPA!: The Global Observatory for Physical Activity; 2016.

33. Tremblay M, Gray CE, Akinroye K, Harrington DM, Katzmarzyk PT, Lambert EV, Liukkonen J, Maddison R, Ocansey RT, Onywera VO, et al. Physical activity of children: a global matrix of grades comparing 15 countries. J Phys Act Health. 2014;11(Suppl 1):S113-25.

34. Tremblay M, Barnes JD, González SA, Katzmarzyk PT, Onywera VO, Reilly JJ, Tomkinson GR. Global matrix 2.0: report card grades on the physical activity of children and youth comparing 38 countries. J Phys Act Health. 2016; 13(11 Suppl 2):S343-66.

35. Colebatch HK. Policy: concepts in the social sciences. Buckingham: Open University Press; 2002

36. Birkland TA. An introduction to the policy process: theories, concepts and models of public policy making. New York and London: Routledge; 2014.

37. Pate RR, Trilk $J$, Wonwoo B, Jing W. Policies to increase physical activity in children and youth. J Exerc Sci Fit. 2011;9(1):1-14.

38. Coenen P, Gilson N, Healy GN, Dunstan DW, Straker LM. A qualitative review of existing national and international occupational safety and health policies relating to occupational sedentary behaviour. Appl Ergon. 2017; 60:320-33.

39. Seppälä T, Hankonen N, Korkiakangas E, Ruusuvuori J, Laitinen J. National policies for the promotion of physical activity and healthy nutrition in the workplace context: a behaviour change wheel guided content analysis of policy papers in Finland. BMC Public Health. 2017;18(1):87.

40. Milton K, Bauman A. A critical analysis of the cycles of physical activity policy in England. Int J Behav Nutr Phys Act. 2015;12:8.

41. Bull F, Milton K, Kahlmeier S. Health-enhancing physical activity (HEPA) policy audit tool (PAT). Copenhagen: World Health Organization, Regional Office for Europe; 2011.

42. Bull F, Milton K, Kahlmeier S. Health-enhancing physical activity (HEPA) policy audit tool (PAT) - version 2. Copenhagen: World Health Organization, Regional Office for Europe; 2015.

43. Brown J, Rosenkranz R, Kolt G, Berentson-Shaw J. A literature review of evidence on physical activity for older people and a review of existing 
physical activity guidelines for older people. New Zealand Guidelines Group and University of Western Sydney; 2011.

44. Christiansen N, Kahlmeier S, Racioppi F. Sport promotion policies in the European Union: results of a contents analysis. Scand J Med Sci Sports. 2014;24(2):428-38.

45. Kustec-Lipicer S. Vrednovanje javnih politika. Zagreb: Disput; 2012

46. World Bank. World Bank list of economies. 2017.

47. Active Healthy Kids Canada. Dropping the ball. Canada's report card on physical activity for children and youth. Toronto: Active Healthy Kids Canada; 2005.

48. Active Healthy Kids Canada. Canada's report card on physical activity for children and youth - 2006. Toronto: Active Healthy Kids Canada; 2006.

49. Active Healthy Kids Canada. Older But Not Wiser. Canada's Future At Risk. Canada's Report Card on Physical Activity for Children and Youth - 2007. Toronto: Active Healthy Kids Canada; 2007.

50. Active Healthy Kids Canada. It's time to unplug our kids. Canada's Report Card on Physical Activity for Children and Youth 2008. Toronto: Active Healthy Kids Canada; 2008.

51. Active Healthy Kids Canada. Active kids are fit to learn. The Active Healthy Kids Canada Report Card on Physical Activity for Children and Youth 2009 Toronto: Active Healthy Kids Canada; 2009.

52. Active Healthy Kids Canada. Healthy habits start earlier than you think. The active healthy kids Canada report card on physical activity for children and youth. Toronto: Active Health Kids Canada; 2010.

53. Active Healthy Kids Canada. Don't let this be the Most physical activity our kids get after school. The active healthy kids Canada 2011 report card on physical activity for children and youth. Toronto: Active Healthy Kids Canada; 2011.

54. Active Healthy Kids Canada. Is active play extinct? The active healthy kids Canada 2012 report card on physical activity for children and youth. Toronto: Active Healthy Kids Canada; 2012.

55. Active Healthy Kids Canada. Are we driving our kids to unhealthy habits? The 2013 active healthy kids Canada report card on physical activity for children and youth. Toronto: Active Healthy Kids Canada; 2013.

56. Active Healthy Kids Canada. Is Canada in the running? The 2014 active healthy kids Canada report card on physical activity for children and youth. Toronto: Active Healthy Kids Canada; 2014.

57. Active Healthy Kids Canada. The Biggest Risk is Keeping Kids Indoors. The ParticipACTION Report Card on Physical Activity for Children and Youth. Toronto: Active Healthy Kids Canada; 2015.

58. Active Healthy Kids Canada. Are Canadian kids too tired to move? The ParticipACTION report card on physical activity for children and youth. Toronto: Active Healthy Kids Canada; 2016.

59. Adeniyi AF, Odukoya OO, Oyeyemi AL, Adedoyin RA, Ojo OS, Metseagharun E, Akinroye KK. Results from Nigeria's 2016 report card on physical activity for children and youth. J Phys Act Health. 2016;13(11 Suppl 2):S231-36.

60. Aguilar-Farias N, Cortinez-O'Ryan A, Sadarangani KP, Von Oetinger A, Leppe J, Valladares M, Balboa-Castillo T, Cobos C, Lemus N, Walbaum M, CristiMontero C. Results from Chile's 2016 report card on physical activity for children and youth. J Phys Act Health. 2016;13(11 Suppl 2):S117-23.

61. Akinroye KK, Oyeyemi AL, Odukoya OO, Adeniyi AF, Adedoyin RA, Ojo OS, Alawode DA, Ozomata EA, Awotidebe TO. Results from Nigeria's 2013 report card on physical activity for children and youth. J Phys Act Health. 2014;11(Suppl 1):S88-92.

62. Al-Bahlani S, Mabry R. Preventing non-communicable disease in Oman, a legislative review. Health Promot Int. 2014;29(Suppl 1):S83-91.

63. Al-Kuwari MG, Ibrahim IA, Hammadi EM, Reilly JJ. Results from Qatar's 2016 active healthy kids report card on physical activity for children and youth. J Phys Act Health. 2016;13(11 Suppl 2):S246-50.

64. Al-Kuwari MG, Ibrahim IA, Hammadi EM, Reilly JJ. Small changes can make a large dirrerence: Qatar Active Healthy Kids Report Card. Doha; 2016.

65. Alderman J, Smith JA, Fried EJ, Daynard RA. Application of law to the childhood obesity epidemic. J Law Med Ethics. 2007;35(1):90-112.

66. Aman MS. Leisure policy in New Zealand and Malaysia: a comparative study of developments in sport and physical recreation. Lincoln, Cantebury: Lincoln University; 2005.

67. Amornsriwatanakul A, Nakornkhet K, Katewongsa P, Choosakul C, Kaewmanee T, Konharn K, Purakom A, Santiworakul A, Sitilertpisan P, Sriramatr S, et al. Results from Thailand's 2016 report card on physical activity for children and youth. J Phys Act Health. 2016;13(11 Suppl 2): S291-98.
68. Amornsriwatanakul A, Nakornkhet K, Katewongsa P, Choosakul C, Kaewmanee T, Konharn K, Purakom A, Santiworakul A, Sitilertpisan P, Sriramatr S, et al. Thailand 2016 Report Card on Physical Activity for Children and Youth: Play More Learn More. 2016.

69. Aro AR, Bertram M, Hamalainen RM, Van De Goor I, Skovgaard T, Valente A, Castellani T, Chereches R, Edwards N. Integrating research evidence and physical activity policy making-REPOPA project. Health Promot Int. 2016; 31(2):430-9.

70. Ballesteros Arribas JM, Dal-Re Saavedra M, Perez-Farinos N, Villar VC. The Spanish strategy for nutrition, physical activity and the prevention of obesity (NAOS strategy). Rev Esp Salud Publica. 2007;81(5):443-9.

71. Barnes JD, Cameron C, Carson V, Chaput J-P, Faulkner GEJ, Janson K, Janssen I, Kramers R, LeBlanc AG, Spence JC, Tremblay MS. Results from Canada's 2016 ParticipACTION report card on physical activity for children and youth. J Phys Act Health. 2016;13(11 Suppl 2):S110-16.

72. Barnes JD, Colley RC, Borghese M, Janson K, Fink A, Tremblay MS. Results from the active healthy kids Canada 2012 report card on physical activity for children and youth. Paediatr Child Health. 2013;18(6):301-4.

73. Bell-Altenstad K, Vail S. Developing public policy for women in sport: a discourse analysis. Can Woman Stud. 1995;15(4):109-12.

74. Bellew B. Review of relevant national strategy-related documents. In: Bull F, Bauman A, Bellew B, Brown W, editors. Getting Australia Active II: An update of evidence on physical activity. Melbourne: National Public Health Partnership (NPHP); 2004. p. 58-89.

75. Bercovitz KL. Canada's active living policy: a critical analysis. Health Promot Int. 1998;13(4):319-28

76. Bergsgard NA, Houlihan B, Mangset P, Nødland SI, Rommetvedt H. Sport policy: a comparative analysis of stability and change. Oxford: ButterworthHeinemann, Elsevier; 2007.

77. Bornstein DB, Pate RR. From Physical Activity Guidelines to a National Activity Plan. J Phys Educ Recreat Dance. 2014;85(7):17-22.

78. Bornstein DB, Pate RR, Buchner DM. Development of a National Physical Activity Plan for the United States. J Phys Act Health. 2014;11(3):463-9.

79. Bornstein DB, Pate RR, Pratt M. A review of the national physical activity plans of six countries. J Phys Act Health. 2009;6(Suppl 2):S245-64.

80. Branca F, Nikogosian H, Lobstein T. The challenge of obesity in the WHO European region and the strategies for response: summary. Copenhagen: World Health Organization; 2007.

81. Bravo G, Silva J. Sport policy in Chile. Int J Sport Policy Pol. 2014;6(1):129-42.

82. Bréchat PH, Vogel $T$, Berthel M, Kaltenbach G, Le Divenah A, Segouin C, Rymer R, Lonsdorfer J. Analysis of fourteen French national programmes on physical activity and sports as determinants of health from 2001 to 2006. Sante Publique (Vandoeuvre-les-Nancy, France). 2009;21(1):101-18.

83. Bull F, Milton K, Kahlmeier S, Arlotti A, Backovic-Jurican A, Belander O, Berlic $\mathrm{N}$, Colitti S, Martin B, Martin E, et al. National policy approaches to promoting physical activity: seven case studies from Europe. Final Technical Report. Perth: The School of Population Health, The University of Western Australia; 2014.

84. Bull F, Milton K, Kahlmeier S, Arlotti A, Backovic-Jurican A, Belander O, Berlic $\mathrm{N}$, Colitti S, Martin B, Martin E, et al. National policy approaches to promoting physical activity: seven case studies from Europe. Final Technical Report 2: full country case studies. Perth: The School of Population Health, The University of Western Australia; 2014

85. Bull F, Milton K, Kahlmeier S, Arlotti A, Juričan A, Belander O, Martin B, Martin-Diener E, Marques A, Mota J. Turning the tide: national policy approaches to increasing physical activity in seven European countries. Br J Sports Med. 2014:49(11):749-56.

86. Bull F, Schoppe S, Bauman A, Weston E. A international review of policies on physical activity. In: Bull F, Bauman A, Bellew B, Brown W, editors. Getting Australia active II - an update of evidence on physical activity. Melbourne: National Public Health Partnership (NPHP); 2004. p. 90-111.

87. Burghard M, Knitel K, van Oost I, Tremblay MS, Takken T. Is our youth cycling to health? Results from the Netherlands' 2016 report card on physical activity for children and youth. J Phys Act Health. 2016;13(11 Suppl 2):S218-24.

88. Burghard M, Knitel K, van Oost I, Tremblay MS, Takken T. Is our Youth Cycling to Health? Dutch 2016 Report Card on: Physical Activity for Children and Youth; 2016.

89. Cavill N, Foster C, Oja P, Martin BW. An evidence-based approach to physical activity promotion and policy development in Europe: contrasting case studies. Promot Educ. 2006;13(2):104-11. 
90. Ceccarelli A. Review of policies adopted in 34 countries to improve diet and physical activity. Ital J Public Health. 2011;8(2):156-71.

91. Chen JD. National policies promoting better nutrition, physical fitness and sports for all in China. In: Simopoulos AP, editor. Nutrition and fitness, evolutionary aspects, children's health, programs and policies. Athens: Karger; 1997. p. 114-21.

92. Chimeddamba O, Peeters A, Walls HL, Joyce C. Noncommunicable disease prevention and control in Mongolia: a policy analysis health policies, systems and management in high-income countries. BMC Public Health. 2015;15:660.

93. Clarke J, Ojo JS. Sport policy in Cameroon. Int J Sport Policy Pol. 2017; 9(1):189-200.

94. Costa Januário CF, de Rebocho Lopes JPS, Carvalho MJ. Public policy: municipalities, sport and government programmes. Revista Intercontinental de Gestão Desportiva. 2012;2(1):74-80.

95. Craig CL. Evolution and devolution of national physical activity policy in Canada. J Phys Act Health. 2011;8(8):1044-56.

96. da Silva EJ. Ideas about physical activity: views on strengthening a nation (World War II). Estudos Ibero-Americanos. 2007;33(2):172-87.

97. de Villiers A, Steyn N, Coopoo Y, Kruger S, Norris S, Puoane T, Draper C, Forbes J, Kolbe-Alexander T, Lambert M, et al. Healthy Active Kids South Africa Report Card 2010. Report card on the physical activity, nutrition and tobacco use for South African children and youth 2010.

98. Dentro KN, Beals K, Crouter SE, Eisenmann JC, McKenzie TL, Pate RR, Saelens BE, Sisson SB, Spruijt-Metz D, Sothern MS, Katzmarzyk PT. Results from the United States' 2014 report card on physical activity for children and youth. J Phys Act Health. 2014;11(Suppl 1):S105-12.

99. Dentro KN, Beals K, Crouter SE, Eisenmann JC, McKenzie TL, Pate RR, Saelens BE, Sisson SB, Spruijt-Metz D, Sothern MS, Katzmarzyk PT. The 2014 United States report card on physical activity for children \& youth. Columbia: National Physical Activity Plan Make the Move. 2014.

100. Draper C, Basset S, De Villiers A, Lambert EV, Uys M, Bartels C, Blomkamp Y, Micklesfield L, Kruger S, Monyeki A, et al. Results from South Africa's 2014 report card on physical activity for children and youth. J Phys Act Health. 2014;11(Suppl 1):S98-104.

101. Draper C, Basset S, De Villiers A, Lambert EV, Uys M, Bartels C, Blomkamp Y, Micklesfield L, Kruger S, Monyeki A, et al. Healthy active kids South Africa report card 2014. 2014.

102. Egger G, Donovan RJ, Giles-Corti B, Bull F, Swinburn B. Developing National Physical Activity Guidelines for Australians. Aust N Z J Public Health. 2001; 25(6):561-3.

103. Eyler A. Promoting Physical Activity through Policy. Research Digest of the President's Council on Fitness, Sports \& Nutrition. 2011;12(3):1-9.

104. Fullagar S. Governing the healthy body: discourses of leisure and lifestyle within Australian health policy. Health. 2002;6(1):69-84.

105. Fullagar SP. Governing women's active leisure: the gendered effects of calculative rationalities within Australian health policy. Crit Public Health. 2003;13(1):47-60.

106. Galaviz Kl, Arroyo MA, González-Casanova I, Villalobos MFG, Jáuregui A, Ulloa EJ, Miranda SP, Rodríguez MP, Pelayo RAR, López-Taylor JR. Results from Mexico's 2016 report card on physical activity for children and youth. J Phys Act Health. 2016;13(11 Suppl 2):S206-12.

107. Gillon P. A human rights-based approach to the discourses governing active recreation in New Zealand. Auckland: Auckland University of Technology; 2010.

108. Gomez EJ. Understanding the United States and Brazil's response to obesity: institutional conversion, policy reform, and the lessons learned. Glob Health. 2015;11:24.

109. González SA, Castiblanco MA, Arias-Gómez LF, Martinez-Ospina A, Cohen DD, Holguin GA, Almanza A, Lemos DMC, Correa-Bautista JE, Escobar ID, et al. Results from Colombia's 2016 report card on physical activity for children and youth. J Phys Act Health. 2016;13(11 Suppl 2):S129-36.

110. González SA, Sarmiento OL, Cohen DD, Camargo DM, Correa JE, Páez DC, Ramírez-Vélez R. Results from Colombia's 2014 report card on physical activity for children and youth. J Phys Act Health. 2014;11(Suppl 1):S33-44.

111. Gray CE, Barnes JD, Bonne JC, Cameron C, Chaput JP, Faulkner G, Janssen I, Katzmarzyk PT, Kolen AM, Manske SR, et al. Results from Canada's 2014 report card on physical activity for children and youth. J Phys Act Health. 2014;11(Suppl 1):S26-32.

112. Green M. Podium or participation? Analysing policy priorities under changing modes of sport governance in the United Kingdom. Int J Sport Policy. 2009;1(2):121-44.
113. Guo H, Pan L. Changes, characteristics and inspirations of American physical activity policy: a text analysis. J Beijing Sport Univ. 2016;39(8) 8-13.

114. Halliday E, Mutrie N, Bull F. Getting Scotland on the move? Reflections on a 5-year review of Scotland's national physical activity strategy. Br J Sports Med. 2013:47(17):1130-2.

115. Hämäläinen RM, Aro AR, Lau CJ, Rus D, Cori L, Syed AM. Cross-sector cooperation in health-enhancing physical activity policymaking: more potential than achievements? Health Res Policy Syst. 2016;14:33.

116. Hämäläinen RM, Aro AR, van de Goor I, Lau CJ, Jakobsen MW, Chereches RM, Syed AM. Exploring the use of research evidence in health-enhancing physical activity policies. Health Res Policy Syst. 2015;13:43.

117. Hämäläinen RM, Sandu P, Syed AM, Jakobsen MW. An evaluation of equity and equality in physical activity policies in four European countries. Int J Equity Health. 2016;15:191.

118. Harrington DM, Belton S, Coppinger T, Cullen M, Donnelly A, Dowd K, Keating T, Layte R, Murphy M, Murphy N, et al. Results from Ireland's 2014 report card on physical activity in children and youth. J Phys Act Health. 2014;11(Suppl 1):S63-8.

119. Harrington DM, Belton S, Coppinger T, Cullen M, Donnelly A, Dowd K, Keating $T$, Layte $R$, Murphy M, Murphy $N$, et al. Ireland's report card on physical activity in children \& youth. Are our children up to the mark? On your marks, get set go! Leicester: Research Group for Ireland's Report Card on Physical Activity in Children and Youth; 2014.

120. Harrington DM, Murphy M, Carlin A, Coppinger T, Donnelly A, Dowd KP, Keating T, Murphy N, Murtagh E, O'Brien W, et al. Results from Ireland north and South's 2016 report card on physical activity for children and youth. J Phys Act Health. 2016;13(11 Suppl 2):S183-88.

121. Harrington DM, Murphy M, Carlin A, Coppinger T, Donnelly A, Dowd KP, Keating T, Murphy N, Murtagh E, O'Brien W, et al. Are our kids moving with the times? The 2016 Ireland North and South Report Card on Physical Activity for Children and Youth. Leicester: Research Group for Ireland's Report Card on Physical Activity in Children and Youth; 2016.

122. Herrera-Cuenca M, Méndez-Perez B, Morales VC, Martín-Rojo J, Tristan B, Bandy AT, Landaeta-Jiménez M, Macías-Tomei C, López-Blanco M. Results from Venezuela's 2016 report card on physical activity for children and youth. J Phys Act Health. 2016;13(11 Suppl 2):S314-29.

123. Herrera-Cuenca M, Méndez-Perez B, Morales VC, Martín-Rojo J, Tristan B, Bandy AT, Landaeta-Jiménez M, Macías-Tomei C, López-Blanco M. The Venezuelan Report Card on Physical Activity for Children and Youth; 2016.

124. Huang WY, Wong H-SS, Wong MC-S, Sit CH-P, Sum RK-W, He G. Results from Hong Kong's 2016 report card on physical activity for children and youth. J Phys Act Health. 2016;13(11 Suppl 2):S169-75.

125. Huang WY, Wong H-SS, Wong MC-S, Sit CH-P, Sum RK-W, He G. The 2016 active healthy kids Hong Kong report card on physical activity for children and youth. Hong Kong: Active Healthy Kids Hong Kong; 2016.

126. Jebb SA, Aveyard PN, Hawkes C. The evolution of policy and actions to tackle obesity in England. Obes Rev. 2013;14(Suppl 2):S42-59.

127. Kahlmeier S, Wijnhoven TMA, Alpiger P, Schweizer C, Breda J, Martin BW National physical activity recommendations: systematic overview and analysis of the situation in European countries. BMC Public Health. 2015;15:133.

128. Kalman M, Hamrík Z. Is the low level of physical activity a public policy issue? Phys Cult / Telesna Kultura. 2013;36(2):96-114.

129. Kalman M, Hamrik Z, Pavelka J, Dohnal T. Promotion of physical activity in the Czech Republic. In: 5th international scientific conference on kinesiology, Kinesiology research trends and applications. Proceedings book. Zagreb: Faculty of Kinesiology; 2008. p. 826-9.

130. Katapally TR, Goenka S, Bhawra J, Mani S, Krishnaveni GV, Kehoe SH, Lamkang AS, Raj M, McNutt K. Results from India's 2016 report card on physical activity for children and youth. J Phys Act Health. 2016;13(11 Suppl 2):S176-82.

131. Katapally TR, Goenka S, Bhawra J, Mani S, Krishnaveni GV, Kehoe SH, Lamkang AS, Raj M, McNutt K. The 2016 India Report Card on Physical Activity for Children and Youth. Johnson Shoyama Graduate School of Public Policy - Canada and the Public Health Foundation of India; 2016.

132. Katikireddi SV, Higgins M, Bond L, Bonell C, Macintyre S. How evidence based is English public health policy? BMJ (Online). 2011;343(7833):1090-3.

133. Katzmarzyk PT, Denstel KD, Beals K, Bolling C, Wright C, Crouter SE, McKenzie TL, Pate RR, Saelens BE, Staiano AE. Results from the United States of America's 2016 report card on physical activity for children and youth. J Phys Act Health. 2016;13(11 Suppl 2):S307-13. 
134. Katzmarzyk PT, Denstel KD, Beals K, Bolling C, Wright C, Crouter SE, McKenzie TL, Pate RR, Saelens BE, Staiano AE. The 2016 United States report card on physical activity for children and youth. Columbia: National Physical Activity Plan Alliance; 2016.

135. Kobayashi T, Hoye R, Nicholson M. Sport Policy in Vanuatu. Int J Sport Policy. 2017;9(4):753-65.

136. Koh KW. Physical activity recommendations and guidelines based on a new paradigm. J Korean Med Assoc. 2010;53(12):1139-46.

137. Kranzler Y, Davidovich N, Fleischman Y, Grotto I, Moran DS, Weinstein R. A health in all policies approach to promote active, healthy lifestyle in Israel. Isr J Health Policy Res. 2013;2:16.

138. Kruusamäe H, Kull M, Mooses K, Riso E-M, Jürimäe J. Results from Estonia's 2016 report card on physical activity for children and youth. J Phys Act Health. 2016;13(11 Suppl 2):S150-56.

139. Kudláček M, Vašíčková J, Neuls F. National policy and mechanisms of development of local infrastructures for leisure-time physical activity - the IMPALA project. Phys Cult / Telesna Kultura. 2012;35(2):9-33.

140. Lachat C, Otchere S, Roberfroid D, Abdulai A, Seret FMA, Milesevic J, Xuereb $\mathrm{G}$, Candeias V, Kolsteren P. Diet and physical activity for the prevention of noncommunicable diseases in low- and middle-income countries: a systematic policy review. PLoS Med. 2013;10:6.

141. Lagos RAS. Sedentary lifestyle, sports and biopolitical pressure for healthy living: discourse analysis on the "choose to live healthy" system in Chile. Movimento. 2016;22(2):391-402.

142. Larsen LR, Troelsen J, Kirkegaard KL, Riiskjær S, Krølner R, Østergaard L, Kristensen PL, Møller NC, Christensen BFN, Jensen JO, et al. Results from Denmark's 2016 report card on physical activity for children and youth. J Phys Act Health. 2016;13(11 Suppl 2):S137-42.

143. Larsen LR, Troelsen J, Kirkegaard KL, Riiskjær S, Krølner R, Østergaard L, Kristensen PL, Møller NC, Christensen BFN, Jensen JO, et al. The Danish Physical Activity Report Card for Children and Youth. Research and Innovation Centre for Human Movement and Learning; 2017.

144. Liu Y, Tang Y, Cao ZB, Chen PJ, Zhang JL, Zhu Z, Zhuang J, Yang Y, Hu YY. Results from Shanghai's (China) 2016 report card on physical activity for children and youth. J Phys Act Health. 2016;13(11 Suppl 2):S124-28.

145. Liukkonen J, Jaakkola T, Kokko S, Gråstén A, Yli-Piipari S, Koski P, Tynjälä J, Soini A, Ståhl T, Tammelin T. Results from Finland's 2014 report card on physical activity for children and youth. J Phys Act Health. 2014;11(Suppl 1): S51-7.

146. Lu W, Henry IP. Historical review of sports policy in rural China (1949-2008). Int J Hist Sport. 2011;28(7):1055-71.

147. Maddison R, Dale LP, Marsh S, LeBlanc AG, Oliver M. Results from New Zealand's 2014 report card on physical activity for children and youth. J Phys Act Health. 2014;11(Suppl 1):S83-7.

148. Maddison R, Marsh S, Hinckson E, Duncan S, Mandic S, Taylor R, Smith M. New Zealand 2016 report card for children and youth. Auckland: National Institute for Health Innovation, The University of Auckland, Auckland University of Technology, and The University of Otago; 2015.

149. Maddison R, Marsh S, Hinckson E, Duncan S, Mandic S, Taylor R, Smith M. Results from New Zealand's 2016 report card on physical activity for children and youth. J Phys Act Health. 2016;13(11 Suppl 2):S225-30.

150. Manyanga T, Makaza D, Mahachi C, Mlalazi TF, Masocha V, Makoni P, Tapera E, Khumalo B, Rutsate SH, Tremblay MS. Results from Zimbabwe's 2016 report card on physical activity for children and youth. J Phys Act Health. 2016:13(11 Suppl 2):S337-42.

151. Manyanga T, Makaza D, Mahachi C, Mlalazi TF, Masocha V, Makoni P, Tapera E, Khumalo B, Rutsate SH, Tremblay MS. Active outdoor play: an affordable but neglected pathway towards a helathy childhood. The 2016 Zimbabwe report card on the physical activity for children and youth. Bulawayo: Zimbabwe Report Card Working Group; 2016.

152. Matalas AL. National programs and policies for promoting better nutrition, fitness and sports for all in Greece. In: Simopoulos AP, editor. Nutrition and fitness, evolutionary aspects, children's health, programs and policies. Athens: Karger; 1997. p. 128-135.

153. Méndez SFV. Promoting physical activity in Mexico: a public policy unfinished. Gestion y Politica Publica. 2015;Volumen Tematico:27-54

154. Milton K, Grix J. Public health policy and walking in England-analysis of the 2008 'policy window'. BMC Public Health. 2015;15:614.

155. Mota J, MJ ES, Raimundo AM, Sardinha LB. Results from Portugal's 2016 report card on physical activity for children and youth. J Phys Act Health. 2016;13(11 Suppl 2):S242-45
156. Murphy P, Waddington I. Sport for all: some public health policy issues and problems. Crit Public Health. 1998;8(3):193-205.

157. Musingarimi P. Obesity in the UK: A Review and Comparative Analysis of Policies within the Developed Regions. London: International Longevity Centre; 2008.

158. Musingarimi P. Obesity in the UK: a review and comparative analysis of policies within the devolved administrations. Health Policy. 2009;91(1):10-6.

159. Nardo N Jr, Silva DAS, de Moraes Ferrari GL, Petroski EL, Pacheco RL, Martins PC, Oliveira LC, Araújo TL, Mendes AA, Lazarin SPB. Results from Brazil's 2016 report card on physical activity for children and youth. J Phys Act Health. 2016;13(11 Suppl 2):S104-09.

160. Nishtar S, Bile KM, Ahmed A, Faruqui AM, Mirza Z, Shera S, Ghaffar A, Minhas FA, Khan A, Jaffery NA. Process, rationale, and interventions of Pakistan's national action plan on chronic diseases. Prev Chronic Dis. 2006;3:1.

161. Nyström CD, Larsson C, Ehrenblad B, Eneroth $H$, Eriksson U, Friberg M, Hagströmer M, Lindroos AK, Reilly JJ, Löf M. Results from Sweden's 2016 report card on physical activity for children and youth. J Phys Act Health. 2016:13(11 Suppl 2):S284-90.

162. Nyström CD, Larsson C, Ehrenblad B, Eneroth $H$, Eriksson U, Friberg M, Hagströmer M, Lindroos AK, Reilly JJ, Löf M. Active Healthy Kids Sweden 2016 On Physical Activity for Children and Youth; 2016.

163. Ocansey R, Aryeetey R, Sofo S, Delali MB, Pambo P, Nyawornota VK. Results from Ghana's 2014 report card on physical activity for children and youth. J Phys Act Health. 2014;11(Suppl 1):S58-62.

164. Ocansey R, Aryeetey R, Sofo S, Nazzar A, Delali M, Pambo P, Nyawornota V, Nartey J, Sarkwa R. Results from Ghana's 2016 report card on physical activity for children and youth. J Phys Act Health. 2016;13(11 Suppl 2):S165-68.

165. Onywera VO, Muthuri SK, Hayker S, Wachira L-JM, Kyallo F, Mang'eni RO, Bukhala P, Mireri C. Results from Kenya's 2016 report card on physical activity for children and youth. J Phys Act Health. 2016;13(11 Suppl 2): S195-200.

166. Onywera VO, Muthuri SK, Hayker S, Wachira L-JM, Kyallo F, Mang'eni RO, Bukhala P, Mireri C. 2016 Kenya's report card on physical activity and body weight of children and youth. Nairobi: Healthy Active Kids Kenya; 2016.

167. Pérez-Escamilla R. The Mexican dietary and physical activity guidelines: moving public nutrition forward in a globalized world. J Nutr. 2016; 146(9):1924S-7S.

168. Piggin J. Power, politics and policy: creating, deploying and resisting meaning in New Zealand public sport policy. Dunedin: University of Otago, School of Physical Education; 2008

169. Piggin J, Hart L. Physical activity advocacy in the UK: a multiple streams analysis of a hybrid policy issue. Leisure Studies. 2017;36(5):708-20.

170. Pilar Rodriguez M, Barnes J, Barriguete A, Brownrigg M, Colley R, Ivimey D, Janssen I, Jauregui E, Robles J, Lopez Y, Taylor JR, Tremblay M. The Mexican report card on physical activity for children and youth. Canada and Mexico Battling Obesity; 2012.

171. Pratt M, Salvo D, Cavill N, Giles-Corti B, McCue P, Reis RS, Jáuregui A, Foster C. An international perspective on the Nexus of physical activity research and policy. Environ Behav. 2016;48(1):37-54

172. Prévot-Ledrich J, Van Hoye A, Lombrail P, Lecomte F, Vuillemin A. Overview of French public policies promoting health-enhancing physical activity. Sante publique (Vandoeuvre-les-Nancy, France). 2016;28(1):S25-31.

173. Prista A, Daca T, Tchonga F, Machava E, Macucule C, Ribeiro E. Results from the Mozambique 2016 report card on physical activity for children and adolescents. J Phys Act Health. 2016;13(11 Suppl 2):S213-17.

174. Prista A, Picardo S, Ribeiro E, Libombo J, Daca T. Results from Mozambique's 2014 report card on physical activity for children and youth. J Phys Act Health. 2014;11(Suppl 1):S79-82.

175. Ramadan J, Vuori I, Lankenau B, Schmid T, Pratt M. Developing a national physical activity plan: the Kuwait example. Glob Health Promot. 2010; 17(2):52-7.

176. Ramirez Varela A, Pratt M, Powell K, Lee IM, Bauman A, Heath G, Martins RC, Kohl H, Hallal PC. Worldwide Surveillance, Policy and Research on Physical Activity and Health: The Global Observatory for Physical Activity - GoPA! J Phys Act Health. 2017:14(9):701-9.

177. Reddy P, Coopoo Y, Norris S, Puoane T, Kruger S, Lambert M, Lambert V, Kolbe-Alexander TL, Steyn N, McQuaide K. Healthy Active Kids South Africa. Report Card on the Physical Activity, Nutrition and Tobacco use for South African Children and Youth. Cape Town: Sports Science Institute of South Africa; 2007. 
178. Reilly JJ, Dick S, McNeill G, Tremblay MS. Child's play 2013? Active Healthy Kids Scotland Report Card. Detailed Methodology and Findings. Glasgow: Active Healthy Kids Scotland; 2013.

179. Reilly JJ, Dick S, McNeill G, Tremblay MS. Results from Scotland's 2013 report card on physical activity for children and youth. J Phys Act Health. 2014; 11(Suppl 1):S93-7.

180. Reilly JJ, Johnstone A, McNeill G, Hughes AR. Results from Scotland's 2016 report card on physical activity for children and youth. J Phys Act Health. 2016;13(11 Suppl 2):S251-55

181. Reilly JJ, Johnstone A, McNeill G, Hughes AR. Long Form Report Card 2016. Glasgow: Active Healthy Kids Scotland; 2016

182. Rodriguez Martinez MDP, Galaviz Kl, Jauregui E, Gonzalez-Casanova I, Lopez Y Taylor JR, Tremblay M, Gray C, Bonne JC, Janssen I, Cisneros AR, et al. The 2014 Mexican Report Card on Physical Activity for Mexican Children and Youth. Canada-Mexico Battling Childhood Obesity (CAMBIO); 2014.

183. Rodriguez Martinez MDP, Galaviz KI, Ulloa EJ, Gonzalez-Casanova I, Lopez Y, Taylor JR. Results from Mexico's 2014 report card on physical activity for children and youth. J Phys Act Health. 2014;11(Suppl 1):S74-8.

184. Roman-Viñas B, Marin J, Sánchez-López M, Aznar S, Leis R, Aparicio-Ugarriza R, Schroder H, Ortiz-Moncada R, Vicente G, González-Gross M, Serra-Majem L. Results from Spain's 2016 report card on physical activity for children and youth. J Phys Act Health. 2016;13(11 Suppl 2):S279-83.

185. Rütten A, Frahsa A, Engbers L, Gusi N, Mota J, Pacenka R, Troelsen J, Vasickova J, Vuillemin A. Supportive environments for physical activity, community action, and policy in 8 European Union member states: comparative analysis and specificities of context. J Phys Act Health. 2013; 11(5):873-83.

186. Salinas J, Vio F. Promoting health and physical activity in Chile: a policy priority. Rev. Panam Salud Publica = Pan Am J Public Health. 2003;14(4):281-8.

187. Schöppe S, Bauman A, Bull F. International review of National Physical Activity Policy - a literature review. Sydney: NSW Centre for Physical Activity and Health; 2004.

188. Schranz N, Olds T, Cliff D, Davern M, Engelen L, Giles-Corti B, Gomersall S, Hardy L, Hesketh K, Hills A, et al. Results from Australia's 2014 report card on physical activity for children and youth. J Phys Act Health. 2014;11(Suppl 1): s21-5.

189. Schranz N, Olds T, Cliff D, Davern M, Engelen L, Giles-Corti B, Gomersall S, Hardy L, Hesketh K, Hills A, et al. Is sport enough? 2014 report card on physical activity for children \& young people. Adelaide: Active Healthy Kids Australia; 2014.

190. Schranz NK, Olds T, Boyd R, Evans J, Gomersall SR, Hardy L, Hesketh K, Lubans DR, Ridgers ND, Straker L. Results from Australia's 2016 report card on physical activity for children and youth. J Phys Act Health. 2016;13(11 Suppl 2):S87-94.

191. Schranz NK, Olds T, Boyd R, Evans J, Gomersall SR, Hardy L, Hesketh K, Lubans DR, Ridgers ND, Straker L, et al. Physical literacy: do our kids have all the tools? 2016 report card on physical activity for children and young people. Adeleide: Active Healthy Kids Australia; 2016.

192. Sember V, Starc G, Jurak G, Golobič M, Kovač M, Samardžija PP, Morrison SA. Results from the Republic of Slovenia's 2016 report card on physical activity for children and youth. J Phys Act Health. 2016;13(11 Suppl 2):S256-64.

193. Sharif R, Chong KH, Zakaria NH, Ong ML, Reilly JJ, Wong JE, Saad HA, Poh BK. Results from Malaysia's 2016 report card on physical activity for children and adolescents. J Phys Act Health. 2016;13(11 Suppl 2):S201-S05.

194. Sharif R, Chong KH, Zakaria NH, Ong ML, Reilly JJ, Wong JE, Saad HA, Poh BK. Malaysia Active Healthy Kids Report Card 2016. Kuala Lumpur: Universiti Kebangsaan Malaysia: Active Healthy Kids Malaysia; 2016.

195. Skille E, Solbakken T. Sport as a vehicle for health promotion - an analysis of Norwegian policy documents. Crit Public Health. 2011;21(2):191-202.

196. Smith A, Jones J, Houghton L, Duffell T. A political spectator sport or policy priority? A review of sport, physical activity and public mental health policy. Int J Sport Policy. 2016;8(4):593-607.

197. Standage M, Wilkie HJ, Jago R, Foster C, Goad MA, Cumming SP. Results from England's 2014 report card on physical activity for children and youth. J Phys Act Health. 2014;11(Suppl 1):S45-50.

198. Stratton G, Cox R, Mannello M, Mattingley R, Robert C, Sage R, Taylor S, Williams S, Tyler R. Active Healthy Kids Wales 2016 Report Card; 2016.

199. Stratton G, Williams C, Taylor S, Jones AM, Mackintosh K, Frost M, Mattingley R, Hopkin G, Williams S. Active Healthy Kids Report Card - Wales; 2014.

200. Stuij M, Stokvis R. Sport, health and the genesis of a physical activity policy in the Netherlands. Int J Sport Policy. 2015;7(2):217-32.
201. Tammelin TH, Aira A, Hakamaki M, Husu P, Kallio J, Kokko S, Laine K, Lehtonen K, Mononen K, Palomaki S, et al. Results from Finland's 2016 report card on physical activity for children and youth. J Phys Act Health. 2016;13(11 Suppl 2):S157-64.

202. Tammelin TH, Aira A, Hakamaki M, Husu P, Kallio J, Kokko S, Laine K, Lehtonen K, Mononen K, Palomaki S, et al. Finland's Report Card 2016 on Physical Activity for Children and Youth. Jyväskylä: LIKES Research Centre for Physical Activity and Health; 2016.

203. Tan T-C. The transformation of China's National Fitness Policy: from a major sports country to a world sports power. Int J Hist Sport. 2015; 32(8):1071-84.

204. Tanaka C, Tanaka S, Inoue S, Miyachi M, Suzuki K, Reilly JJ. Results from Japan's 2016 report card on physical activity for children and youth. J Phys Act Health. 2016;13(11 Suppl 2):S189-94.

205. Tanaka C, Tanaka S, Inoue S, Miyachi M, Suzuki K, Reilly JJ. The 2016 Japan report card on physical activity for children and youth. Tokyo: Japanese Society of Physical Fitness and Sports Medicine; 2016.

206. Tremblay MS, Warburton DE, Janssen I, Paterson DH, Latimer AE, Rhodes RE, Kho ME, Hicks A, LeBlanc AG, Zehr L. New Canadian physical activity guidelines. Appl Physiol Nutr Metab. 2011;36(1):36-46.

207. Tyler R, Mannello M, Mattingley R, Roberts C, Sage R, Taylor SR, Ward M, Williams S, Stratton G. Results from Wales' 2016 report card on physical activity for children and youth: is Wales turning the tide on Children's inactivity? J Phys Act Health. 2016;13(11 Suppl 2):S330-36.

208. Uys M, Bassett S, Draper CE, Micklesfield L, Monyeki A, de Villiers A, Lambert EV. Results from South Africa's 2016 report card on physical activity for children and youth. J Phys Act Health. 2016;13(11 Suppl 2):S265-73.

209. Vallgårda S. Governing obesity policies from England, France, Germany and Scotland. Soc Sci Med. 2015;147:317-23.

210. van Mechelen W. National policies for promoting physical activity, physical fitness and better nutrition in Europe. In: Simopoulos AP, editor. Nutrition and Fitness, Evolutionary Aspects, Children's Health, Programs and Policies. Athens: Karger; 1997. p. 136-47.

211. Vuori I, Paronen O, Oja P. How to develop local physical activity promotion programmes with national support: the Finnish experience. Patient Educ Couns. 1998;33(1 Suppl):S111-9.

212. Wachira L, Muthuri SK, Tremblay MS, Onywera VO. Results from Kenya's 2014 report card on the physical activity and body weight of children and youth. J Phys Act Health. 2014;11(Suppl 1):S69-73.

213. Wachira L, Muthuri SK, Tremblay MS, Onywera VO. Kenya's 2014 Report Card on Physical Activity and Body Weight of Children and Youth. Ontario and Nairobi: Healthy Active Kids Kenya and Active Healthy Kids Canada; 2014

214. Wijtzes Al, Verloigne M, Mouton A, Cloes M, De Ridder KA, Cardon G, Seghers J. Results from Belgium's 2016 report card on physical activity for children and youth. J Phys Act Health. 2016;13(11 Suppl 2):S95-103.

215. Wijtzes Al, Verloigne M, Mouton A, Cloes M, De Ridder KA, Cardon G, Seghers J. The 2016 Belgium report card on physical activity for children and youth. Leuven: KU Leuven; 2016.

216. Wilkie H, Standage M, Sherar L, Cumming S, Parnell C, Davis A, Foster C, Jago R. Results from England's 2016 report card on physical activity for children and youth. J Phys Act Health. 2016;13(11 Suppl 2):S143-49.

217. Wilkie H, Standage M, Sherar L, Cumming S, Parnell C, Davis A, Foster C, Jago R. Then \& Now? The 2016 Active Healthy Kids England Report Card of Physical Activity for Children and Youth; 2016.

218. Woods CB, Mutrie N. Putting Physical Activity on the Policy Agenda. Quest. 2012;64(2):92-104.

219. Wu BR. Understanding network governance: a case study exploration of active Canada 20/20. St. Catharines: Brock University; 2015.

220. Xu S, Xiao H, Tan X. Physical activity: elements of US National Health Policy-Based on the American program 'Healthy Citizen'. J Shanghai Phys Educ Inst / Shanghai Tiyu Xueyuan Xuebao. 2014;38(1):25-30.

221. Yoonkyung $S$, Hyuk In $Y$, Eun-Young L, Mi-Seong $Y$, Min Jae $K$, Hyun Joo K, Wook S, YeonSoo K, Hyon P, Han Joo L, et al. Results from South Korea's 2016 report card on physical activity for children and youth. J Phys Act Health. 2016;13(11 Suppl 2):S274-78.

222. Yoonkyung $S$, Hyuk In $Y$, Eun-Young L, Mi-Seong $Y$, Min Jae $K$, Hyun Joo K, Wook S, YeonSoo K, Hyon P, Han Joo L, et al. 2016 South Korea report card on physical activity for children and youth. Where we stand as a nation and how to move forward. Yonsei University, Kyung Hee University, and Seul National University; 2016 
223. Zaabi MA, Shah SM, Sheek-Hussein M, Abdulle A, Junaibi AA, Loney T. Results from the United Arab Emirates' 2016 report card on physical activity for children and youth. J Phys Act Health. 2016;13(11 Suppl 2):S299-306.

224. Zaabi MA, Shah SM, Sheek-Hussein M, Abdulle A, Junaibi AA, Loney T. Have Children in the UAE Deserted Physical Activity? United Arab Emirates 2016 Report Card on Physical Activity for Children and Adolescents; 2016.

225. Zembura P, Goldys A, Nalecz H. Results from Poland's 2016 report card on physical activity for children and youth. J Phys Act Health. 2016;13(11 Suppl 2):S237-41.

226. Gråstén A, Liukkonen J, Jaakkola T, Tammelin T. Finnish report card 2014 on physical activity for children and youth. Jyväskylä: University of Jyväskylä and LIKES - Research Center for Sport and Health Sciences. 2014.

227. World Health Organization. Nutrition, physical activity and the prevention of obesity. Policy developments in the WHO European Region. Copenhagen: World Health Organization, Reginal Office for Europe; 2007.

228. World Health Organization. Report of the 2 nd meeting of National Information Focal Points: Copenhagen, Denmark, 23-24 June 2009. Copenhagen: World Health Organization, Regional Office for Europe; 2010.

229. World Health Organization. Meeting of WHO nutrition counterparts and National Information Focal Points for the WHO/EC monitoring project, Geneva Switzerland, 24-25 March 2010. Geneva: World Health Organisation, Regional Office for Europe; 2010.

230. World Health Organization. Socio-environmentally determined health inequities among children and adolescents - Summary of outcomes, background papers and country case studies. Copenhagen: World Health Organization, Regional Office for Europe; 2010.

231. World Health Organization. Promoting sport and enhancing health in European Union countries: a policy content analysis to support action Copenhagen: World Health Organization, Regional Office for Europe; 2011.

232. World Health Organization. Promoting physical activity in the Eastern Mediterranean Region through a life-course approach. Cairo: World Health Organization, Regional Office for the Eastern Mediterranean; 2014.

233. World Health Organization. Factsheets on Health-Enhanching Physical Activity in the 28 European Union Member States of the WHO European Region. Copenhagen: World Health Organization, Regional Office for Europe; 2015.

234. Oja P, Titze S. Physical activity recommendations for public health: development and policy context. EPMA. 2011;2 (3):253-59.

235. Active Healthy Kids. Who we are. https://www.activehealthykids.org/aboutus/. Accessed 20 Mar 2017.

236. Colley RC, Brownrigg M, Tremblay MS. A model of knowledge translation in health: the active healthy kids Canada report card on physical activity for children and youth. Health Promot Pract. 2012;13(3):320-30.

237. Active Healthy Kids Global Alliance. Core Physical Activity Indicators. https:// www.activehealthykids.org/tools/. Accessed 11 Feb 2017.

238. Landes RG. The Canadian polity: A comparative introduction. Scarborough: Prentice Hall; 1991.

239. Physical Activity Policy Research Network. What is Physical Activity Policy? https://paprn.wustl.edu/about-us/Pages/WhatisPhysicalActivityPolicy.aspx. Accessed 20 Dec 2017

240. World Health Organization. Health Promotion Glossary. Geneva: World Health Organization; 1998.

241. World Health Organization. Health Policy. http://www.who.int/topics/ health_policy/en/. Accessed 20 Dec 2017.

242. Rabotnikof N. En busca de un lugar común: el espacio público en la teoría política contemporánea. Mexico: Instituto de Investigaciones FilosoficasUNAM; 2005.

243. Meny I, Thoenig JC. Lãs políticas públicas. Barcelona: Ariel SA; 1992.

244. Jenkins WI. Policy analysis: A political and organisational perspective. London: M. Robertson; 1978.

245. Rütten A, Abu-Omar K, Gelius P, Dinan-Young S, Frändin K, Hopman-Rock $M$, Young A. Policy assessment and policy development for physical activity promotion: Results of an exploratory intervention study in 15 European Nations. Health Res Policy Syst. 2012;10:14.

246. Alwan A, Maclean D, Mandil A. Assessment of National Capacity for Noncommunicable Disease Prevention and Control. The Report of a Global Survey. Geneva: World Health Organization; 2001.

247. World Health Organization. Report of the Global Survey on the Progress in National Chronic Diseases Prevention and Control. Geneva: World Health Organization; 2007.
248. World Health Organization. Assessing national capacity for the prevention and control of noncommunicable diseases. Report of the $2010 \mathrm{global}$ survey. Geneva: World Health Organization; 2012.

249. World Health Organization. Assessing national capacity for the prevention and control of noncommunicable diseases. Report of the 2013 global survey. Geneva: World Health Organization; 2014.

250. Lasswell HD, Lerner D, Fisher HH. The policy sciences: Recent developments in scope and method. Palo Alto: Stanford University Press; 1951.

251. Althaus C, Bridgman P, Davis G. The Australian policy handbook. Melbourne: Allen \& Unwin; 2013.

252. Morestin F. A framework for analyzing public policies: Practical guide. Québec: Centre de collaboration nationale sur les politiques publiques et la santé, Institut national de santé publique; 2012.

253. HM Treasury. The Magenta Book: Guidance for evaluation. London: Crown; 2011.

254. Bardach E, Patashnik EM. A practical guide for policy analysis: The eightfold path to more effective problem solving. Washington: CQ press, SAGE Publications; 2015

255. Kahlmeier S, Milton K, Cavill N, Giné-Garriga M, Galán-Mercant A, Ley V, Krtalic S, Martin-Diener E, Mota J, Valente A, et al. Auditing national physical activity policies: applications, dissemination and lessons learned from the HEPA Policy Audit Tool (PAT). Zurich: EPHEPA; 2017.

\section{Ready to submit your research? Choose BMC and benefit from:}

- fast, convenient online submission

- thorough peer review by experienced researchers in your field

- rapid publication on acceptance

- support for research data, including large and complex data types

- gold Open Access which fosters wider collaboration and increased citations

- maximum visibility for your research: over $100 \mathrm{M}$ website views per year

At BMC, research is always in progress.

Learn more biomedcentral.com/submissions 